\title{
Taxonomic revision of water-bloom-forming species of oscillatorioid cyanobacteria
}

\footnotetext{
${ }^{1}$ National Institute for Environmental Studies, 16-2 Onogawa, Tsukuba, Ibaraki 305-8506, Japan

2 Department of Applied Biological Chemistry, Graduate School of Agricultural and Life Sciences, The University of Tokyo, Yayoi, Bunkyo-ku, Tokyo 113-8657, Japan

3 Thailand Institute of Science and Technological Research, 196 Phahonyothin Rd, Chatuchak, Bangkok 10900, Thailand

${ }^{4}$ Research and Development Institute, Kasetsart University, Bangkok 10900, Thailand

${ }^{5}$ Institute of Hydrobiology, Chinese Academy of Science, Wuhan, Hubei 430072, PR China

${ }^{6}$ Culture Collection of Algae and Protozoa, CEH Windermere, Far Sawrey, Ambleside, Cumbria LA22 OLP, UK
}

\author{
Shoichiro Suda, ${ }^{1} \dagger$ Makoto M. Watanabe, ${ }^{1}$ Shigeto Otsuka, ${ }^{2}$ \\ Aparat Mahakahant, ${ }^{3}$ Wichien Yongmanitchai, ${ }^{4}$ \\ Napavarn Nopartnaraporn, ${ }^{4}$ Yongding Liu ${ }^{5}$ and John G. Day ${ }^{6}$ \\ Author for correspondence: Makoto M. Watanabe. Tel: +8129850 2555. Fax: +81 298502577. \\ e-mail:mmw@nies.go.jp
}

\begin{abstract}
A polyphasic approach was used to clarify the taxonomy of the water-bloomforming oscillatorioid cyanobacteria. Seventy-five strains of oscillatorioid cyanobacteria were characterized by 165 rDNA sequence analysis, DNA base composition, DNA-DNA hybridization, fatty acid composition, phycobilin pigment composition, complementary chromatic adaptation, morphological characters, growth temperature and salinity tolerance. Phylogenetic analysis based on 165 rDNA sequences divided the strains into six groups, all of which were clearly separated from the type species of the genus Oscillatoria, Oscillatoria princeps Gomont NIVA CYA 150. Therefore, these strains should be classified into genera other than Oscillatoria. Groups I-III were closely related to one another and groups IV-VI were distinct from one another and from groups I to III. Group I was further divided into two subgroups, group I-pc, which includes strains containing only phycocyanin (PC), and group I-pe, which includes strains containing large amounts of phycoerythrin (PE) in addition to PC. This phenotypic distinction was supported by DNA-DNA hybridization studies. Based on the properties examined herein and data from traditional, botanical taxonomic studies, the groups and subgroups were classified into single species and we propose either emended or new taxonomic descriptions for Planktothrix agardhii (type strain NIES 204'), Planktothrix rubescens (type strain CCAP 1459/22' ${ }^{\mathrm{T}}$ ), Planktothrix pseudagardhii sp. nov. (type strain T1-8-4'), Planktothrix mougeotii (type strain TR1-5'), Planktothricoides raciborskii gen. nov., comb. nov. (type strain NIES 207'), Tychonema bourrellyi (type strain CCAP 1459/11B') and Limnothrix redekei (type strain NIVA CYA 277/1'T).
\end{abstract}

Keywords: cyanobacteria, water bloom, oscillatorioid, nomenclature, taxonomy

\section{INTRODUCTION}

Historically, the taxonomy of the Cyanophyceae (cyanobacteria) has been formulated under the International Code of Botanical Nomenclature and based primarily on phenotypic characters (Bourrelly, 1985; Desikachary, 1959; Geitler, 1932). However, more recently, the stability of these phenotypic characters and their use in taxonomy have been

† Present address: Marine Biotechnology Institute, Kamaishi Laboratories, Heita, Kamaishi, Iwate 026-0001, Japan.

Abbreviations: $\mathrm{PC}$, phycocyanin; $\mathrm{PE}$, phycoerythrin.

The GenBank/EMBL/DDBJ accession numbers for the 16S rDNA sequences obtained in this study are listed in Table 1. questioned by a number of authors (reviewed by Anagnostidis \& Komárek, 1988). The cell organization of the Cyanophyceae is obviously prokaryotic; therefore, bacteriological taxonomic approaches have been suggested for the Cyanophyceae (see Stanier et al., 1978). In fact, the cyanobacteria are treated as one branch of the oxygenic photosynthetic bacteria in Bergey's Manual of Systematic Bacteriology (Castenholz \& Waterbury, 1989), which is restricted to the genus and order levels and includes guidelines useful for describing novel species and redescribing species poorly characterized under the Botanical Code. These guidelines include the use of morphological, biochemical, genetic, physiological and ecological characteristics. 
Table 1. Strains investigated in this study

Culture collections are abbreviated as CCAP (Culture Collection of Algae and Protozoa, UK), NIES (National Institute for Environmental Studies, Japan) and NIVA (Norwegian Institute for Water Research). Other strains were originally isolated from PR China, Japan and Thailand. Scientific names are given according to culture collection catalogues (CCAP, NIES and NIVA). NK, Not known.

\begin{tabular}{|c|c|c|c|}
\hline Strain & Location of isolation & Collection date & $\begin{array}{c}\text { 16S rDNA } \\
\text { accession no. }\end{array}$ \\
\hline \multicolumn{4}{|c|}{ Oscillatoria agardhii Gomont } \\
\hline CCAP $1459 / 11 \mathrm{~A}$ & Windermere, Cumbria, UK & 1975 & AB045896 \\
\hline CCAP $1459 / 11 B^{T}$ & Loughgall, Northern Ireland, UK & 1971 & AB045897 \\
\hline CCAP $1459 / 15$ & Lough Neagh, Northern Ireland, UK & 1979 & AB045898 \\
\hline CCAP $1459 / 16$ & Blelham Tarn, Cumbria, UK & 1979 & AB045899 \\
\hline CCAP $1459 / 22^{\mathrm{T}}$ & Lake Gjersjøen, Norway (= NIVA CYA $18^{\mathrm{T}}$ ) & 1971 & AB045901 \\
\hline CCAP $1459 / 36$ & Lake Gjersjøen, Norway (= NIVA CYA 29) & 1968 & AB045903 \\
\hline NIES $204^{\mathrm{T}}$ & Lake Kasumigaura, Ibaraki, Japan & Aug. 1983 & AB045954 \\
\hline NIES 205 & Lake Kasumigaura, Ibaraki, Japan & Sep. 1982 & AB045955 \\
\hline NIES 594 & Northern Ireland, UK & NK & AB045956 \\
\hline NIES 595 & Northern Ireland, UK & NK & AB045957 \\
\hline NIES 596 & Veluwemeer, The Netherlands & NK & AB045958 \\
\hline NIES $610^{\mathrm{T}}$ & Lake Gjersjøen, Norway (= NIVA CYA $18^{\mathrm{T}}$ ) & 1971 & AB045959 \\
\hline NIVA CYA 15 & Lake Kolbotnvatnet, Akershus, Norway & 1976 & AB045923 \\
\hline NIVA CYA 21 & Gulf of Finland, Helsinki, Finland & 1973 & AB045927 \\
\hline NIVA CYA 29 & Lake Gjersjøen, Akershus, Norway & 1968 & AB045931 \\
\hline NIVA CYA 34 & Lake Kolbotnvatnet, Akershus, Norway & 1976 & $\mathrm{AB} 045935$ \\
\hline NIVA CYA 59 & Lake Jarenvatnet, Oppland, Norway & 1978 & AB045939 \\
\hline NIVA CYA $61 / 1$ & Lake Kolbotnvatnet, Akershus, Norway & 1978 & AB045940 \\
\hline NIVA CYA $64 / 6$ & Lake Helgetjernet, Østfold, Norway & 1979 & AB045941 \\
\hline NIVA CYA 68 & Lake Veluwemeer, The Netherlands & ca. 1977 & AB045943 \\
\hline NIVA CYA 105 & Lake Brunnsjön, Hedemora, Dalarne, Sweden & 1982 & AB045908 \\
\hline NIVA CYA 116 & Lake Årungen, Akershus, Norway & 1983 & AB045911 \\
\hline NIVA CYA 126 & Lake Långsjön, Åland, Finland & 1984 & AB045914 \\
\hline NIVA CYA 127 & Lake Vesijärvi, Lahti, Finland & 1984 & $\mathrm{AB} 045915$ \\
\hline NIVA CYA 153 & Chao Phya, Bangkok, Thailand & 1984 & AB045922 \\
\hline NIVA CYA 229 & Lake Östra, Kyrksundet, Åland, Finland & 1987 & AB045928 \\
\hline \multicolumn{4}{|c|}{ O. agardhii Gomont var. } \\
\hline NIVA CYA $18^{\mathrm{T}}$ & Lake Gjersjøen, Akershus, Norway & 1971 & AB045925 \\
\hline NIVA CYA 35 & Lake Kolbotnvatnet, Akersus, Norway & 1976 & AB045937 \\
\hline NIVA CYA 73 & Lake Kolbotnvatnet, Akershus, Norway & 1980 & AB045944 \\
\hline NIVA CYA 85 & Lake Gjersjöen, Akershus, Norway & 1981 & AB048945 \\
\hline NIVA CYA 87 & Lake Levrasjön, Skåne, Sweden & 1981 & AB045946 \\
\hline NIVA CYA 90 & Lilla Ullfjärden, Lake Mälaren, Uppland, Sweden & 1982 & AB045948 \\
\hline NIVA CYA 98 & Lake Steinsfjorden, Buskerud, Norway & 1982 & $\mathrm{AB} 045951$ \\
\hline NIVA CYA 108 & Stora Ullfjärden, Lake Mälaren, Uppland, Sweden & 1982 & AB045909 \\
\hline NIVA CYA 128 & Lake Vesijärvi, Lahti, Finland & 1984 & AB045916 \\
\hline NIVA CYA 129 & Lake Långsjön, Åland, Finland & 1984 & AB045917 \\
\hline NIVA CYA 151 & Lake Almind sø, Denmark & 1984 & AB045921 \\
\hline NIVA CYA 320 & Lake Kolbotnvatnet, Akershus, Norway & 1993 & AB045934 \\
\hline \multicolumn{4}{|c|}{ O. agardhii var. isothrix Skuja } \\
\hline CCAP $1459 / 21$ & Esthwaite Water, Cumbria, UK & 1985 & AB045900 \\
\hline CCAP $1459 / 23$ & Esthwaite Water, Cumbria, UK & 1985 & AB045902 \\
\hline NIVA CYA 9 & Lake Frøylandsvatn, Rogaland, Norway & 1964 & AB045952 \\
\hline NIVA CYA 10 & Lake Gjersjøen, Akershus, Norway & 1964 & AB045910 \\
\hline NIVA CYA 11 & Lake Akersvatn, Vestfold, Norway & 1964 & $\mathrm{AB} 045913$ \\
\hline NIVA CYA 30 & Lake Frøylandsvatnet, Norway & 1968 & AB045932 \\
\hline NIVA CYA $56 / 3$ & Lake Steinsfjorden, Buskerud, Norway & 1978 & AB045938 \\
\hline NIVA CYA 65 & Lake Vansjø, Østfold, Norway & 1979 & AB045942 \\
\hline
\end{tabular}




\begin{tabular}{|c|c|c|c|}
\hline Strain & Location of isolation & Collection date & $\begin{array}{c}\text { 16S rDNA } \\
\text { accession no. }\end{array}$ \\
\hline NIVA CYA $88 / 3$ & Lake Ören, Åtvidanberg, Östergötland, Sweden & 1981 & AB045947 \\
\hline NIVA CYA 91 & Lake Mälaren, Sweden & 1982 & AB045949 \\
\hline NIVA CYA $117 / 3$ & Lake Gjersjøen, Akershus, Norway & 1983 & AB045912 \\
\hline NIVA CYA 133 & Lake Øgderen, Akershus, Norway & 1984 & AB045918 \\
\hline NIVA CYA 137 & Lake Steinsfjorden, Buskerud, Norway & 1984 & AB045919 \\
\hline NIVA CYA 168 & Windermere, Cumbria, UK & 1975 & AB045924 \\
\hline NIVA CYA 297 & Lake Frøylandsvatnet, Norway & 1990 & AB045930 \\
\hline NIVA CYA 313 & River Oder-Talsperre, Germany & 1992 & AB045933 \\
\hline \multicolumn{4}{|c|}{ Oscillatoria raciborskii Woloszynska } \\
\hline NIES $207^{\mathrm{T}}$ & Lake Kasumigaura, Ibaraki, Japan & Jun. 1983 & AB045960 \\
\hline \multicolumn{4}{|c|}{ Oscillatoria rubescens DC. ex Gomont } \\
\hline NIVA CYA 1 & Zürichsee, Switzerland & 1958 & AB045926 \\
\hline \multicolumn{4}{|c|}{ O. rubescens DC. ex Gomont var. } \\
\hline NIVA CYA 13 & Lake Steinsfjorden, Buskerud, Norway & 1965 & AB045920 \\
\hline NIVA CYA 55 & Lake Steinsfjorden, Buskerud, Norway & 1978 & AB045937 \\
\hline NIVA CYA $97 / 5$ & Lake Steinsfjorden, Buskerud, Norway & 1982 & AB045950 \\
\hline \multicolumn{4}{|c|}{ Oscillatoria redekei Van Goor } \\
\hline NIVA CYA $277 / 1^{\mathrm{T}}$ & Lake Mälaren, Sweden & 1990 & AB045929 \\
\hline \multicolumn{4}{|l|}{ Oscillatoria sp. } \\
\hline $\mathrm{C} 1-12$ & Lake Dian-chi, Kunming, Yunan, PR China & Feb. 1996 & AB045904 \\
\hline $\mathrm{C} 1-17$ & Lake Dian-chi, Kunming, Yunan, PR China & Feb. 1996 & AB 045905 \\
\hline CW4-5 & Lake Dalai, Inner Mongolia, PR China & Jul. 1996 & AB045907 \\
\hline $\mathrm{T} 1-8-4^{\mathrm{T}}$ & Bangkok, Thailand & Jan. 1996 & AB045968 \\
\hline $\mathrm{T} 19-6^{\prime}-6$ & Moat of King's Palace, Bangkok, Thailand & Mar. 1996 & AB045965 \\
\hline T19-6'-8 & Moat of King's Palace, Bangkok, Thailand & Mar. 1996 & AB045966 \\
\hline INBaOR & Lake Inbanuma, Chiba, Japan & Aug. 1995 & AB045953 \\
\hline T1-6-2 & Bangkok, Thailand & Mar. 1996 & AB045967 \\
\hline OR 1-1 & Bangkok, Thailand & Mar. 1996 & AB045964 \\
\hline NSLAØ3* & Lake Alexandrina, New South Wales, Australia & 1990 & AB045962 \\
\hline NSLAØ4* & Lake Alexandrina, New South Wales, Australia & 1990 & AB045963 \\
\hline TK4-5 & Bangkok, Thailand & Mar. 1996 & AB045969 \\
\hline TK5-1 & Bangkok, Thailand & Mar. 1996 & AB045970 \\
\hline TR $1-5^{\mathrm{T}}$ & Nakhon Pathon, Thailand & Mar. 1996 & AB045971 \\
\hline TR2-4 & Nakhon Pathon, Thailand & Mar. 1996 & AB045972 \\
\hline \multicolumn{4}{|c|}{ Oscillatoria princeps Gomont } \\
\hline NIVA CYA 150 & Chao Phya, Bangkok, Thailand & 1984 & AB045961 \\
\hline \multicolumn{4}{|c|}{ Lyngbya hieronymusii Lemmermann } \\
\hline CN4-3 & Lake Dalai, Inner Mongolia, PR China & Jul. 1996 & AB045906 \\
\hline
\end{tabular}

* Strains were obtained from CSIRO, Australia.

Although cyanobacterial taxonomy should be studied using bacteriological approaches, species-name priority rests with the Botanical Code (Castenholz \& Waterbury, 1989). Therefore, it is necessary to develop a bacteriological classification system from the existing botanical assemblage of names so that compatibility and continuity with the traditional botanical classification system are preserved. For this reason, the characteristics of axenic clones of each cyanobacterial morphospecies (botanical species) should be investigated according to the guidelines (Castenholz \& Waterbury, 1989) for bacteriological approaches.

In this paper, the taxonomy of water-bloom-forming species of freshwater oscillatorioid cyanobacteria is reexamined by employing the multidisciplinary criteria recommended by Castenholz \& Waterbury (1989). Oscillatoria agardhii and related planktonic species such as Oscillatoria rubescens, Oscillatoria mougeotii, Oscillatoria raciborskii and Oscillatoria redekei commonly form water-blooms and, in some cases, produce toxins or excrete geosmin-like substances that reduce water quality and prevent the use of water-bodies for drinking and recreation (Skulberg \& Skulberg, 1985; Persson, 1996). These water-bloom-forming species share common morphological characters, such as the presence of gas vacuoles and similar cell dimensions. The taxonomic delimitation of each taxon is difficult to 
achieve. In addition, the heterogeneous characters of $O$. agardhii have caused confusion in its intra-specific taxonomy (Elenkin, 1949; Skuja, 1948; Pringsheim, 1965). The above factors have stimulated interest in both the identification and classification of $O$. agardhii and related species. Although taxonomic confusion still exists at the species level (Kützing, 1849; Lemmermann, 1907 or 1910; Geitler, 1932; Elenkin, 1949), $O$. agardhii, O. rubescens, $O$. mougeotii and $O$. raciborskii were included in a new genus, Planktothrix, with the type species Planktothrix agardhii by Anagnostidis \& Komárek (1988). O. redekei, which is distinguished from the other oscillatorioids mentioned above by having very narrow cells and two large, polar gas vacuoles, was considered to belong to a different genus (Limnothrix) by Meffert (1988).

In this study, 75 strains that were, or may be, assigned to the above five taxa of water-bloom-forming oscillatorioid cyanobacteria were obtained from culture collections or were freshly isolated. The phylogeny of these 75 strains was analysed from their $16 \mathrm{~S}$ rDNA sequences. In addition, DNA base composition, fatty acid profiles, phycobilin pigment content, morphology and growth at different temperatures and salinities were investigated. Furthermore, DNA-DNA hybridization experiments were performed to define the taxonomic relationship between closely related groups. This paper presents suggested taxonomic revisions of the water-bloom-forming oscillatorioid cyanobacteria based on data derived from this polyphasic taxonomic study.

\section{METHODS}

Strains and growth conditions. Seventy five strains of waterbloom-forming oscillatorioid cyanobacteria assigned to $O$. agardhii, $O$. agardhii var., $O$. agardhii var. isothrix, $O$. raciborskii, $O$. rubescens, $O$. rubescens var. and Oscillatoria sp. and one strain each of Oscillatoria princeps and Lyngbya hieronymusii var. hieronymusii were obtained from NIES (National Institute for Environmental Studies, Japan) (Watanabe \& Hiroki, 1997), CCAP (Culture Collection of Algae and Protozoa, UK) (Tompkins et al., 1995) and NIVA (Norwegian Institute of Water Research) (Skulberg, 1990) or isolated from lakes and reservoirs in Japan, PR China and Thailand (Table 1). Strains that were not axenic and/or clonal were purified and cloned by the micropipettewashing method (Hoshaw \& Rosowski, 1973). The purity of the strains was checked with bacterial check media (Watanabe \& Hiroki, 1997) and light microscopy. Stock cultures were maintained in screw-capped test tubes $(18 \times 150 \mathrm{~mm})$ with $10 \mathrm{ml} \mathrm{CT}$ medium (Watanabe \& Hiroki, 1997) and incubated at $20 \pm 1{ }^{\circ} \mathrm{C}$, under a $12 \mathrm{~h}: 12 \mathrm{~h}$ light/ dark cycle at $30 \mu \mathrm{mol}$ photons $\mathrm{m}^{-2} \mathrm{~s}^{-1}$ provided by day-light fluorescent lamps (National Co. Ltd, Japan).

$16 S$ rDNA sequence analyses. Each strain was grown in a 21 Erlenmeyer flask containing 1.51 medium with aeration $\left(1.51 \mathrm{~min}^{-1}\right)$. After 4 weeks of cultivation, cells were harvested by centrifugation $\left(10 \mathrm{~min}, 5^{\circ} \mathrm{C}, 5000 \mathrm{~g}\right)$ and washed with distilled water. DNA for PCR templates was extracted from the cells according to Palinska et al. (1996). Primers for amplification and sequencing were designed
Table 2. PCR primer names, sequences and target sites

Positions of target sites refer to the Escherichia coli sequence.

\begin{tabular}{|llc|}
\hline Primer & \multicolumn{1}{c|}{ Sequence $\left(\mathbf{5}^{\prime} \rightarrow \mathbf{3}^{\prime}\right)$} & Target site \\
\hline 16SF1 & TAACACATGCAAGTCGAACG & $49-68$ \\
16SR1 & GCCGATTGAGGCACGGTCGT & $523-504$ \\
16SF2 & CTACGGGAGGCAGCAGTGGGGA & $342-363$ \\
16SR2 & CATCAGGATGCCATTTGCTA & $821-800$ \\
16SF3 & GTGTAGCGGTGAAATGCGTAG & $683-703$ \\
16SR3 & CCTCCTTCCACTCCTACTGCA & $1194-1174$ \\
16SF4 & GCATGGCTGTCGTCAGCTCG & $1053-1072$ \\
16SR4 & CTTCAGCATTGTTCCATCGGCA & $1512-1491$ \\
\hline
\end{tabular}

based on cyanobacterial 16S rDNA sequences (Table 2) and $16 \mathrm{~S}$ rDNA sequences were amplified from the extracted DNA. PCR was performed in a 50-100 $\mu 1$ reaction mixture using $0.05 \mathrm{U}$ AmpliTaq DNA polymerase $\mu^{-1}$ (Perkin Elmer), buffer with $1.5 \mathrm{mM} \mathrm{MgCl}_{2}$ supplied by Perkin Elmer, $0.2 \mathrm{mM}$ dNTPs, $0.5 \mu \mathrm{M}$ primers and $0.01-0.05 \mu \mathrm{l}$ genomic DNA solution (100-500 $\left.\mathrm{ng} \mu \mathrm{l}^{-1}\right)$. The reactions were run in a Thermal Cycler (Takara Biomedicals) with one cycle of $92^{\circ} \mathrm{C}$ for $2 \mathrm{~min}, 56^{\circ} \mathrm{C}$ for $2 \mathrm{~min}$ and $70{ }^{\circ} \mathrm{C}$ for $3 \mathrm{~min}$ and then 29 cycles of $92^{\circ} \mathrm{C}$ for $1.5 \mathrm{~min}, 56^{\circ} \mathrm{C}$ for $2 \mathrm{~min}$ and $70{ }^{\circ} \mathrm{C}$ for $3 \mathrm{~min}$, followed by $72^{\circ} \mathrm{C}$ for $15 \mathrm{~min}$. The amplification products were purified by using MicroSpin S-400 HR columns (Pharmacia LKB) and sequencing reactions were performed using a Thermo Sequenase fluorescent-labelled primer cycle sequencing kit with 7-deaza-dGTP (Amersham). The reaction products were run on a $4 \%$ Long Ranger gel (FMC Bio Products) using an ALF DNA sequencer (Pharmacia LKB) with autofluorescence primers, the sequences of which were the same as those of the primers used for PCR (Table 2). Both strands were sequenced.

Phylogenetic analysis. The $16 \mathrm{~S}$ rDNA sequences from 77 strains, including $L$. hieronymusii var. hieronymusii and $O$. princeps, were aligned and analysed by comparison with the aligned dataset from the rRNA WWW Server at the University of Antwerp (Van de Peer et al., 1997). Sequences determined in this study, or not recorded in this database, were added individually to the aligned dataset through a profile alignment process using CLUSTAL W version 1.71 (Thompson et al., 1994). Finally, the alignment was refined manually. The dataset contained 1361 positions with hypervariable regions, ambiguous sequences and gaps. This set was used subsequently for phylogenetic analysis among closely related strains. Synechocystis sp. PCC 6803 and Gloeobacter violaceus PCC 7421 were used as outgroups for the phylogenetic analysis. Hypervariable regions, ambiguous sequences and gaps were then removed as suggested by Turner (1997) to obtain a set containing 1182 positions that was used for phylogenetic analysis of 39 cyanobacteria strains, Rhodospirillum rubrum ATCC $11170^{\mathrm{T}}$ and Agrobacterium tumefaciens $\mathrm{K}-\mathrm{Hg}-3$. Phylogenetic trees were generated on the basis of the neighbour-joining method (Saitou \& Nei, 1987). Neighbour-joining analysis was performed using PAUP* $4.0 \beta$ version, running on a Macintosh computer (Swofford, 1999), with each topology checked using 1000 bootstrap replications (Kimura's twoparameter correction). Accession numbers are given in Table 1. The accession numbers of the reference sequences from 


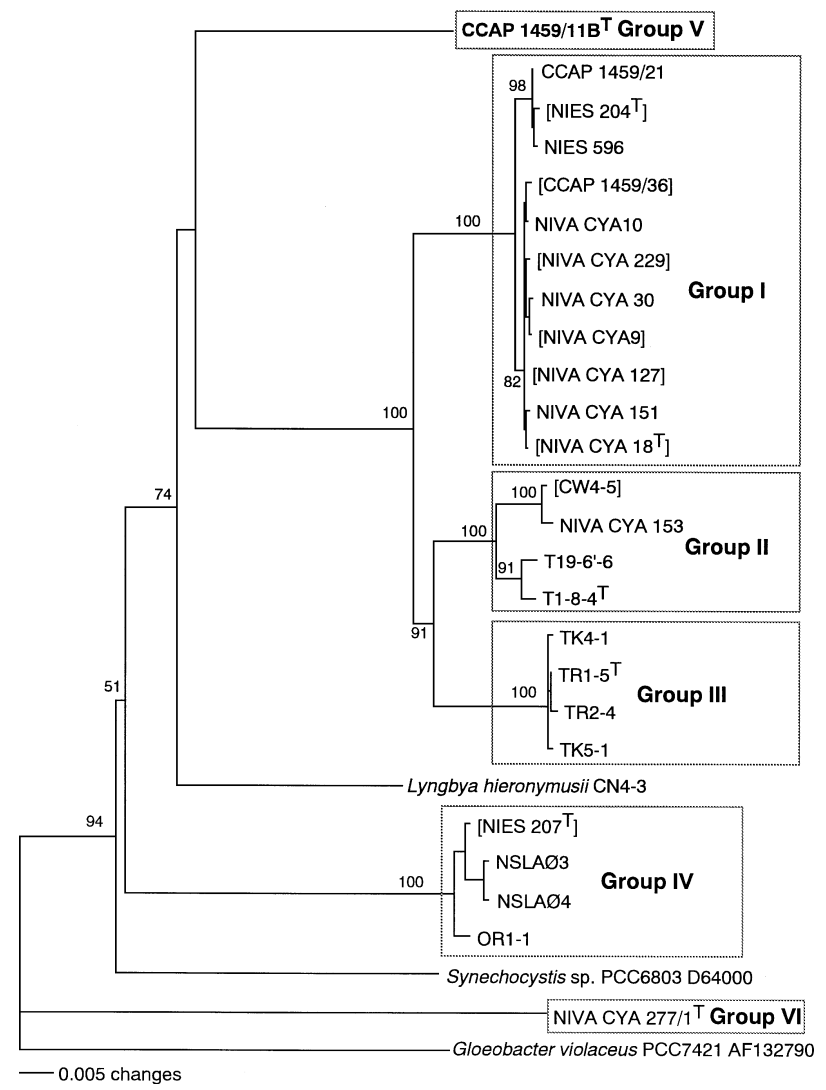

Fig. 1. Phylogenetic tree based on $16 \mathrm{~S}$ rDNA sequences of water-bloom-forming oscillatorioids and related cyanobacteria displaying the positions of strains of groups I-VI. The neighbour-joining tree was based on 1361 nucleotide positions, including variable regions and gaps. Numbers at the branching points are bootstrap values expressed as percentages of 1000 replications; values $<50 \%$ were omitted. Strains in brackets are representatives of strains showing identical sequences: [NIES 204 ${ }^{\top}$ ] represents the sequences of NIES 204 ${ }^{\top}$, CCAP 1349/15, C1-12, C1-17, NIVA CYA 21, 64, 68, 105, 116 and 126 and NIES 205, 594 and 595; [CCAP 1459/36] represents the sequences of CCAP 1459/36 and NIVA CYA 29, 59 and 137; [NIVA CYA 127] represents the sequences of NIVA CYA 127, NIVA CYA 56 and 313; [NIVA CYA 18 ${ }^{\top}$ ] represents the sequences of NIVA CYA $18^{\top}$, CCAP 1459/11A, 1459/16, 1459/22 and 1459/23, NIVA CYA $1,13,35,55,61,65,73,85,87,88,90,91$, $97,98,108,117,128,129,133,168,297$ and 320 and NIES $610^{\top}$; [NIVA CYA 229] represents the sequences of NIVA CYA 229 and NIVA CYA 34; [NIVA CYA 9] represents the sequences of NIVA CYA 9, NIVA CYA 11 and 15; [CW4-5] represents the sequences of CW4-5 and T19-6'-8; and [NIES 207'] represents the sequences of NIES $207^{\top}$, INBaOR and T1-6-2.

EMBL/GenBank/DDBJ are listed on the phylogenetic trees (Figs 1 and 2).

DNA base composition. Approximately $10 \mathrm{mg}$ lyophilized cells or $0.5 \mathrm{ml}$ cell pellet from fresh cultures was used for the analysis. Isolation and enzymic hydrolysis of DNA were performed according to Tamaoka \& Komagata (1984) and analyses were performed using reverse-phase HPLC (Shimadzu) equipped with an SPD-10A UV/VIS spectrophotometric detector and a Cosmosil $5 \mathrm{C} 18$ column $(4.6 \mathrm{~mm}$ i.d. $\times 150 \mathrm{~mm}$; Nakarai). Nucleosides were eluted with a mixture of $0.4 \mathrm{M} \mathrm{NH}_{4} \mathrm{H}_{2} \mathrm{PO}_{4}$ and acetonitrile $(40: 1, \mathrm{v} / \mathrm{v})$ at a flow rate of $1 \mathrm{ml} \mathrm{min}^{-1}$ at $40{ }^{\circ} \mathrm{C}$ controlled by a column oven (Shimadzu CTO-6A). Each nucleoside was detected by absorbance at $270 \mathrm{~nm}$. Each sample was analysed at least three times from the DNA isolation procedure.

Fatty acid composition. Samples (5-10 mg lyophilized cells) were transmethylated with $2 \mathrm{ml} 5 \%$ methanol/HCl (TCI$\mathrm{SU}^{\mathrm{TH}}$, Japan) at $100{ }^{\circ} \mathrm{C}$ for $3 \mathrm{~h}$. After cooling to room temperature, the methylated acids were extracted with $1.5 \mathrm{ml}$ $n$-hexane and washed with $0.5 \mathrm{ml}$ distilled water. The hexane layer was transferred to a new glass tube and concentrated to a volume of approximately $100 \mu \mathrm{l}$ by vacuum evaporation. A $1 \mu \mathrm{l}$ aliquot of the concentrated sample was injected into a Shimadzu GC-17A gas chromatograph equipped with a hydrogen flame-ionization detector and a capillary column $(25 \mathrm{~m} \times 0.25 \mathrm{~mm} \times 0.25 \mu \mathrm{m})$ coated with methyl silicon as the polar stationary phase (007-FFAP; Tokyo Kasei). The

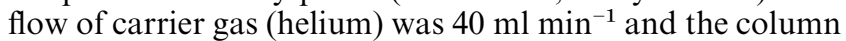
temperature was programmed to increase from 130 to $220^{\circ} \mathrm{C}$ at $5{ }^{\circ} \mathrm{C} \mathrm{min}^{-1}$. Methyl esters were identified by co-chromatography of authentic standards (Sigma) and by mass spectroscopy. The relative concentrations of fatty acids were calculated by comparing the areas under the chromatographic peaks with a data processor (C-R6A; Shimadzu).

In vivo and phycobiliprotein absorption spectra. Exponential-phase cells were used for determination of in vivo and phycobiliprotein absorption spectra. An aliquot of culture was transferred to a spectrophotometric cuvette $(4 \mathrm{ml})$ and the in vivo absorption spectrum was measured from 350 to $850 \mathrm{~nm}$ by using a Hitachi type U-3000 spectrophotometer equipped with a $60 \mathrm{~mm}$-diameter integrating sphere device. For phycobiliprotein absorption spectra, an aliquot of 5-15 ml culture was centrifuged at $500 \mathrm{~g}$ for $15 \mathrm{~min}$ at room temperature. The pellet was suspended in potassium phosphate buffer $(\mathrm{pH} 6.5)$ and the cells were broken in a bead beater (5000 r.p.m., two periods of $30 \mathrm{~s}$ ) at about $5^{\circ} \mathrm{C}$. The broken cell suspension was centrifuged $(500 \mathrm{~g}, 15 \mathrm{~min})$ to remove unbroken cells. The crude supernatant was centrifuged $(80000 \mathrm{~g}, 1 \mathrm{~h})$ in an ultracentrifuge (Beckman L7-55) and the absorbance of the supernatant was measured from 350 to $750 \mathrm{~nm}$ as described above.

Complementary chromatic adaptation. Each strain was cultured separately under continuous light with pure green (20-S-G-F, National Co. Ltd) or pure red (20-S-R-F, National Co. Ltd) fluorescent lamps $\left(20 \mu \mathrm{E} \mathrm{m}^{-2} \mathrm{~s}^{-1}\right)$ at $20 \pm 1^{\circ} \mathrm{C}$. Phycobiliprotein absorption spectra were then determined spectrophotometrically for each strain as described above.

Morphology. Morphological observations were made using an Olympus Vanox photomicroscope equipped with phasecontrast and Nomarski optics systems. The mean cell size and standard deviation of 50 cells were measured for each strain.

Temperature and salinity experiments. Experimental cultures inoculated with one or two filaments from the stock culture were grown at five different temperatures, 10, 20,30, 40 and $50^{\circ} \mathrm{C}\left( \pm 1^{\circ} \mathrm{C}\right)$, and at eight different salinities, approximately $0 \cdot 08$ (original CT medium), $0 \cdot 17,0 \cdot 26,0 \cdot 43$, $0 \cdot 78,1 \cdot 28,1.83$ and $3.58 \% \mathrm{NaCl}(\mathrm{w} / \mathrm{v})$. Growth was checked visually after 14 and 28 days. Each experiment was done in triplicate.

DNA-DNA hybridization. DNA extraction and purification were done according to Tamaoka \& Komagata (1984). Microplate hybridization procedures were performed according to Ezaki et al. (1989) with extracted DNA further purified by ultracentrifugation (Hamamoto \& Nakase, 1995) 


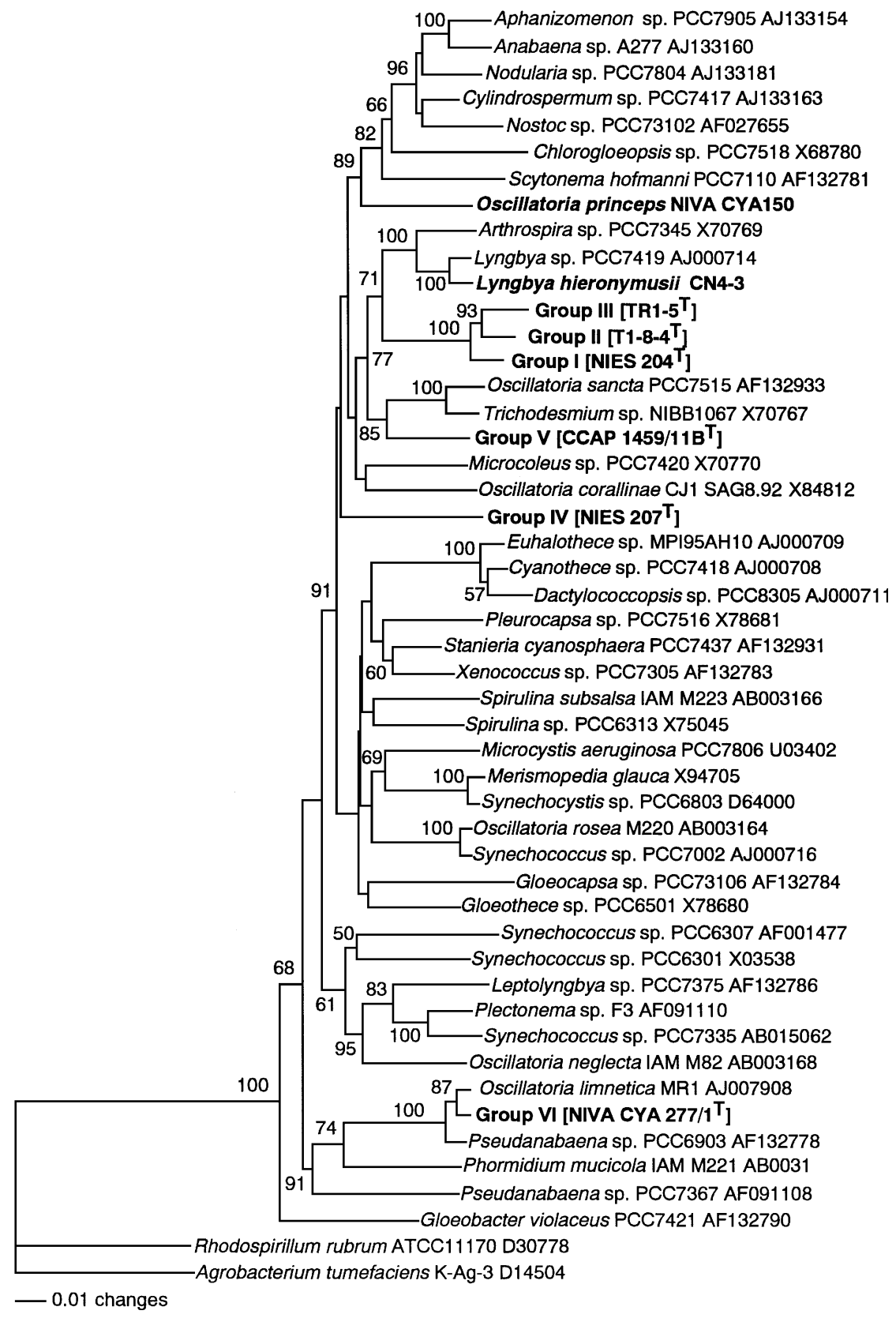

Fig. 2. Phylogenetic tree based on $16 \mathrm{~S}$ rDNA sequence of water-bloom-forming oscillatorioids and related cyanobacteria displaying the positions of strains of groups I-VI, O. princeps NIVA CYA 150 and L. hieronymusii CN4-3 with other cyanobacterial taxa. The neighbour-joining tree was based on 1182 nucleotide positions that excluded hypervariable regions. Numbers at the branching points are bootstrap values expressed as percentages of 1000 replications; values $<50 \%$ were omitted. Strains in brackets are representative of the groups.

and measured by a CytoFluor 4000 (Perseptive Biosystems). Biotin-labelled DNA was prepared from $O$. agardhii NIES $204^{\mathrm{T}}$ and $O$. rubescens CCAP $1459 / 22^{\mathrm{T}}$.

\section{RESULTS}

Phylogenetic analysis of the conserved regions of 16S rDNA

All the oscillatorioid strains sequenced in this study were found to have identical $16 \mathrm{~S}$ rDNA lengths,
$1361 \mathrm{bp}$, corresponding to positions 101-1469 of the Escherichia coli numbering system. Although some of the 75 strains of water-bloom-forming oscillatorioids had identical sequences, six distinct groups were recognized (Fig. 1). Group I consisted of 58 strains sharing more than $99 \cdot 2 \%$ similarity of $16 \mathrm{~S}$ rDNA, group II contained five strains sharing more than $98.4 \%$ similarity, group III contained four strains sharing more than $99.8 \%$ similarity and group IV contained six strains sharing more than $99 \cdot 1 \%$ simi- 
Table 3. Fatty acid composition and DNA G $+C$ content of 165 rDNA groups

\begin{tabular}{|lcccrrr|}
\hline Fatty acid & I & II & III & IV & V & VI \\
\hline $14: 0$ & $2 \cdot 0$ & $2 \cdot 3$ & $2 \cdot 7$ & $2 \cdot 1$ & $2 \cdot 5$ & $32 \cdot 8$ \\
$16: 0$ & $27 \cdot 0$ & $33 \cdot 3$ & $36 \cdot 4$ & $55 \cdot 1$ & $31 \cdot 7$ & $11 \cdot 7$ \\
$16: 1^{*}$ & & & & & $0 \cdot 9$ & $5 \cdot 0$ \\
$16: 1 c$ & $16 \cdot 1$ & $24 \cdot 4$ & $17 \cdot 1$ & $1 \cdot 0$ & & $1 \cdot 0$ \\
$16: 2$ & $1 \cdot 9$ & $0 \cdot 6$ & & & $4 \cdot 9$ & \\
$16: 3$ & & & & & $12 \cdot 0$ & \\
$18: 0$ & $2 \cdot 6$ & $0 \cdot 8$ & $1 \cdot 3$ & $1 \cdot 2$ & $0 \cdot 9$ & $1 \cdot 3$ \\
$18: 1$ & $2 \cdot 7$ & $2 \cdot 8$ & $5 \cdot 3$ & $2 \cdot 5$ & $0 \cdot 7$ & $4 \cdot 5$ \\
$18: 2$ & $9 \cdot 1$ & $10 \cdot 9$ & $14 \cdot 1$ & $1 \cdot 7$ & $10 \cdot 6$ & $7 \cdot 8$ \\
$18: 3 \gamma$ & & & & $1 \cdot 3$ & & \\
$18: 3 \alpha$ & $38 \cdot 7$ & $24 \cdot 9$ & $23 \cdot 2$ & $9 \cdot 8$ & $35 \cdot 8$ & $36 \cdot 0$ \\
$18: 4$ & & & & $25 \cdot 2$ & & \\
Fatty acid type $\dagger$ & $2 \mathrm{~B}$ & $2 \mathrm{~B}$ & $2 \mathrm{C}$ & 4 & $2 \mathrm{~A}$ & $2 \mathrm{C}^{\prime}$ \\
DNA G+C content (mol \%) $+39 \cdot 5 \pm 0 \cdot 4$ & $39 \cdot 5 \pm 0 \cdot 2$ & $40 \cdot 0 \pm 0 \cdot 2$ & $44 \cdot 0 \pm 0 \cdot 4$ & $44 \cdot 4 \pm 0 \cdot 6$ & $40 \cdot 9 \pm 0 \cdot 3$ \\
\hline
\end{tabular}

* Double-bond position not determined.

$\dagger$ Fatty acid composition types of cyanobacteria according to Kenyon (1972), Kenyon et al. (1972), Murata et al. (1992) and Li et al. (1998).

$\$$ Means \pm standard deviation of triplicate measurements.

larity. Groups I-III had less than $96 \cdot 8 \%$ similarity to one another and group IV had less than $89 \cdot 7 \%$ similarity to groups I-III. Groups V and VI contained single strains, CCAP $1459 / 11 \mathrm{~B}^{\mathrm{T}}(\mathrm{V})$ and NIVA CYA $277 / 1^{\mathrm{T}}$ (VI). These strains respectively had less than 91.9 and $86.4 \%$ similarity to the other groups.

A phylogenetic tree based on 1361-bp 16S rDNA sequences revealed that the six groups were divided into four large clusters (Fig. 1). The first cluster contained groups I-III, the second contained group IV, the third contained group $\mathrm{V}$ and the fourth contained group VI. Groups I, II and III formed independent subclusters, each with high bootstrap values. This result suggests that each group is an independent taxon.

Six strains, NIES $204^{\mathrm{T}}$, T1-8-4 ${ }^{\mathrm{T}}$, TR $1-5^{\mathrm{T}}$, NIES $207^{\mathrm{T}}$, CCAP $1459 / 11 \mathrm{~B}^{\mathrm{T}}$ and NIVA CYA $277 / 1^{\mathrm{T}}$, were selected as representatives of each group. A phylogenetic tree based on the 1182-bp 16S rDNA sequences is shown in Fig. 2. In the phylogenetic tree, the type species of Oscillatoria, O. princeps, appeared as a sister group of the Nostocales/Stigonematales clade (Fig. 2). This topology was not stable but different operational taxonomic units and algorithms used for phylogenetic analyses revealed that $O$. princeps NIVA CYA 150 , NIES 204 ${ }^{\mathrm{T}}$ (group I), T1-8-4 ${ }^{\mathrm{T}}$ (group II), TR1-5 (group III), NIES $207^{\mathrm{T}}$ (group IV), CCAP $1459 / 11 \mathrm{~B}^{\mathrm{T}}$ (group V) and NIVA CYA $277 / 1^{\mathrm{T}}$ (group VI) were separated from each other and formed independent clusters (data not shown). Other strains assigned to the genus Oscillatoria on the phylogenetic tree (Fig. 2), Oscillatoria sancta PCC 7515; Oscillatoria corallinae CJ1 SAG8.92, Oscillatoria rosea M220, Oscillatoria limnetica MR1 and Oscillatoria neglecta M82, were placed in clusters different from the type species of Oscillatoria, O. princeps.

\section{DNA base composition}

The DNA base compositions of the 75 strains were summarized for each group recognized by $16 \mathrm{~S}$ rDNA sequences (Table 3). Group I (58 strains) had a mean $\mathrm{G}+\mathrm{C}$ content of $39.5 \pm 0.4 \mathrm{~mol} \%$. The highest value obtained was $40 \cdot 8 \pm 0 \cdot \overline{4} \mathrm{~mol} \%$ (NIVA CYA 30 ) and the lowest was $38.6 \pm 0.4 \mathrm{~mol} \%$ (NIVA CYA 108 ). Group II, including five strains, showed a mean of $39.5 \pm 0.2 \mathrm{~mol} \%$. The highest value was $40 \cdot 6 \pm 0.1 \mathrm{~mol} \% \quad\left(\mathrm{~T} 1-8-4^{\mathrm{T}}\right)$ and the lowest was $38 \cdot 3 \pm 0 \cdot 2 \mathrm{~mol} \%$ (CW4-5). Group III, including four strains, showed a mean of $40 \cdot 0 \pm 0 \cdot 2 \mathrm{~mol} \%$, with a maximum of $41 \cdot 4 \pm 0 \cdot 2 \mathrm{~mol} \%$ (TK5-1) and a minimum of $39 \cdot 5 \pm 0 \cdot 2 \mathrm{~mol} \%$ (TR2-4, TK4-1). Group IV includes six strains and the mean was $44 \cdot 0 \pm 0 \cdot 4 \mathrm{~mol} \%$. Group V, including the single strain CCAP $1459 / 11 \mathrm{~B}^{\mathrm{T}}$, showed a value of $44 \cdot 4 \pm 0 \cdot 6 \mathrm{~mol} \%$. Group VI, including the single strain NIVA CYA $277 / 1^{\mathrm{T}}$, showed a value of $40 \cdot 9 \pm 0 \cdot 3 \mathrm{~mol} \%$.

\section{Fatty acid composition}

Of the 75 strains of water-bloom-forming oscillatorioid cyanobacteria studied, fatty acid profiles were obtained for 73 strains (Table 3 ). All strains contained $14: 0,16: 0,16: 1 c, 18: 0,18: 1,18: 2$ and $18: 3 \alpha$ as major fatty acids. Strains of groups I, II, III, V and VI were characterized by having 18:0,18:1,18:2 and $18: 3 \alpha$ but no $18: 3 \gamma$ or $18: 4$, and strains of group IV were characterized by having all of these fatty acids. On the basis of previous work (Kenyon, 1972; Kenyon et al., 1972; Murata et al., 1992), cyanobacterial strains were 

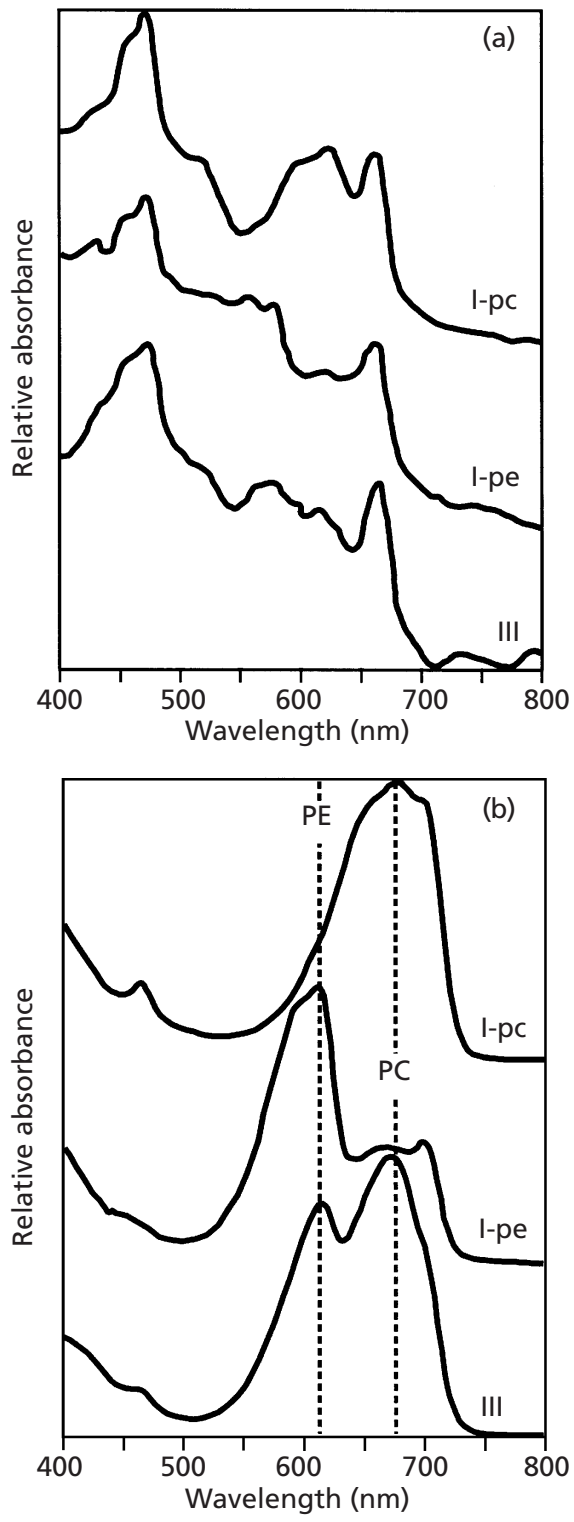

Fig. 3. In vivo absorption spectra (a) and phycobiliprotein absorption spectra (b) of strains C1-12 (group I-pc), CCAP $1459 / 22^{\top}$ (group I-pe) and TR1-5 (group III).

categorized as type 1 , possessing saturated (18:0) and monounsaturated (18:1) fatty acids, type 2 , possessing $18: 0$ to $18: 3 \alpha$ but no $18: 3 \gamma$ and $18: 4$, type 3 , possessing $18: 0$ to $18: 3 \alpha$ and $18: 3 \gamma$ but no $18: 4$, and type 4 , possessing 18:0 to $18: 4$. According to this classification system, group I, II, III, V and VI strains were classified as type 2 and group IV as type 4 . Type 2 could be further separated into two subtypes based on the species of 16-carbon fatty acids; type 2A (Anabaena type) contained 16:0 to 16:3 and type 2B (Oscillatoria type) contained 16:0 to 16:2 (Li et al., 1998). Group V was defined as type $2 \mathrm{~A}$ and strains of groups I and II were type 2B (Table 3). Groups III and VI were assigned to type 2 and had no 16:2 (Table 3 ); they were defined as representing a new subtype, type $2 \mathrm{C}$. In addition to definitions of these subtypes, the fatty acid composition of group VI was characterized further as containing a $16: 1$ fatty acid with the double bond in a different position from $16: 1 c$ and large amounts of 14 : 0 , thereby being defined as type $2 \mathrm{C}^{\prime}$.

\section{Phycobilin pigment composition and chromatic adaptation}

The 58 strains of group I contained two types of phycobilin pigment composition. One type had a large valley in the in vivo absorption spectrum around $550 \mathrm{~nm}$ (Fig. 3a) and a large absorption peak around $630 \mathrm{~nm}$ of the phycobiliprotein absorption spectrum (Fig. 3b), which indicated that they contain phycocyanin (PC) but no phycoerythrin (PE). Forty strains of group I showed this type of phycobilin pigment composition and were designated as group I-pc. The same patterns were indicated in strains of groups II and IV. The other strains in group I had no valley in the absorption spectrum around $550 \mathrm{~nm}$ (Fig. 3a) and possessed large and small absorption peaks, respectively, around 570 and $630 \mathrm{~nm}$ (Fig. 3b). Thus, they contained both PE and PC and had a high PE:PC ratio. In total, 18 strains of group I showed this type of phycobilin pigment composition and were designated as group I-pe. The same patterns were indicated in groups V and VI. Strains of group III had a small valley in their in vivo absorption spectrum around $550 \mathrm{~nm}$ (Fig. 3a) and small and relatively large peaks, respectively, around 570 and $630 \mathrm{~nm}$ of the phycobiliprotein absorption spectrum (Fig. 3b). This indicated that they contained both PE and PC and had a low $\mathrm{PE}: \mathrm{PC}$ ratio.

When the strains of groups I-pc, I-pe, II, III and IV were grown under red or green light, their trichome colour did not change and the in vivo and phycobiliprotein absorption spectra showed the same patterns as those obtained when cultures were incubated under standard light conditions. When the group $\mathrm{V}$ strain CCAP $1459 / 11 \mathrm{~B}^{\mathrm{T}}$ was grown under green light, trichomes were reddish purple or reddish brown in colour and the absorption peak around $570 \mathrm{~nm}$ became much larger (Fig. 4a). In contrast, when it was grown under red light, the trichome colour was pale blue-green and the absorption peak around $570 \mathrm{~nm}$ was conspicuously smaller (Fig. 4a). These data suggest that the strain has the ability to undergo complementary chromatic adaptation by altering the PE content. When the group IV strain NIVA CYA $277 / 1^{\mathrm{T}}$ was grown under red light, the trichome mass colour was pale blue-green with no peak of in vivo absorption around $570 \mathrm{~nm}$ but a large peak around $630 \mathrm{~nm}$ (Fig. 4b). In contrast, when it was grown under green light, the trichome mass colour was reddish purple or reddish brown with large and small peaks, respectively, around 570 and $630 \mathrm{~nm}$ of the in vivo absorption spectrum (Fig. 4b). These data suggest that the strain has the ability to undergo complementary chromatic adaptation by altering both $\mathrm{PC}$ and $\mathrm{PE}$ contents. 

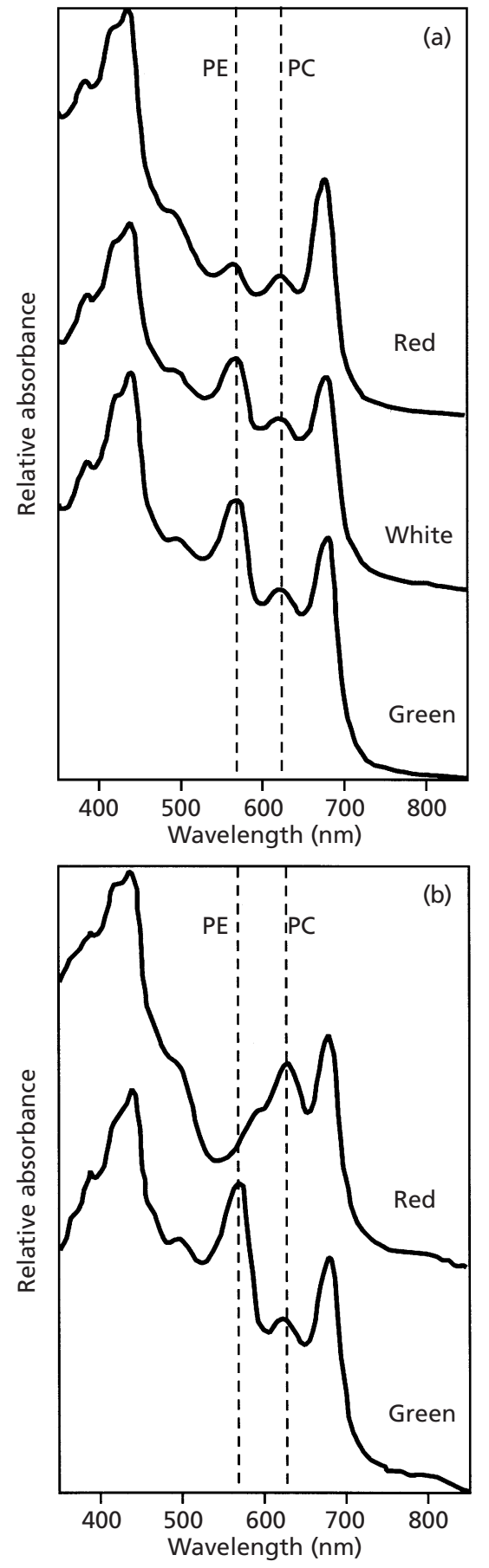

Fig. 4. In vivo absorption spectra of strains CCAP (1459)/11 $\mathrm{B}^{\top}$ (group V) (a) and NIVA CYA $277 / 1^{\top}$ (group VI) (b) under red, white [CCAP (1459)/11 $\mathrm{B}^{\top}$ only] and green light.

\section{Growth at different temperatures and salinities}

On the basis of molecular and chemotaxonomic characteristics, the strains used in this study were separated into seven different groups and subgroups, groups I-pc, I-pe, II, III, IV, V and VI. The temperature ranges of growth of groups I-IV are shown in

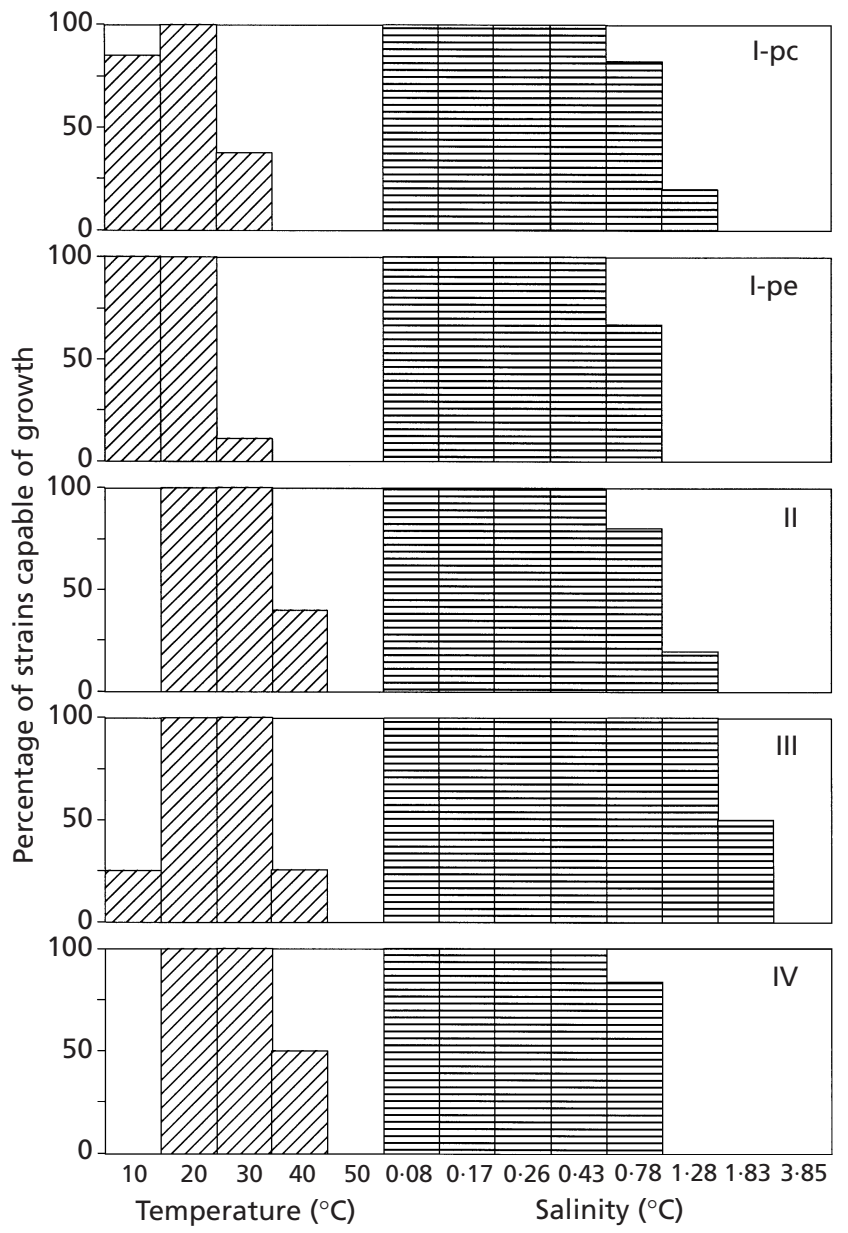

Fig. 5. Growth at different temperatures and salinities. Percentages of strains capable of growth are shown. Groups V and $\mathrm{VI}$, which each include only one strain, were omitted.

Fig. 5. Group I-pc grew mainly in the range $10-20{ }^{\circ} \mathrm{C}$ (some strains also grew at $30^{\circ} \mathrm{C}$ ), most strains of group I-pe grew at $10-20{ }^{\circ} \mathrm{C}$, group II grew at $20-30{ }^{\circ} \mathrm{C}$ (some also grew at $40{ }^{\circ} \mathrm{C}$ ), group III grew at $20-30{ }^{\circ} \mathrm{C}$ (some also grew at 10 and/or $40^{\circ} \mathrm{C}$ ), group IV grew at $20-30{ }^{\circ} \mathrm{C}$ (half of this group also grew at $40^{\circ} \mathrm{C}$ ) and groups V and VI grew at $20-30{ }^{\circ} \mathrm{C}$. From these data, the strains could be separated into two groups, those that grew at $10-20{ }^{\circ} \mathrm{C}$ (groups I-pc, I-pe, V and VI) and those that grew at $20-30{ }^{\circ} \mathrm{C}$ (groups II, III and IV).

Salinity tolerances of groups I-IV are also shown in Fig. 5. Many strains of groups I-pc and II grew in medium with up to $0.78 \% \mathrm{NaCl}$ (some also grew at up to $1.28 \%$ ), many strains of groups I-pe and IV grew at up to $0.78 \%$ (none up to $1.28 \%$ ) and all strains of group III grew at up to $1.28 \%$ (half of them also grew at up to $1.83 \%$ ). Groups V (CCAP $1459 / 11 \mathrm{~B}^{\mathrm{T}}$ ) and VI (NIVA CYA $277 / 1^{\mathrm{T}}$ ) respectively grew in media with up to 0.43 and $0.26 \% \mathrm{NaCl}$ (data not shown). From the data obtained, the cyanobacterial strains could be separated into three groups on the basis of their 

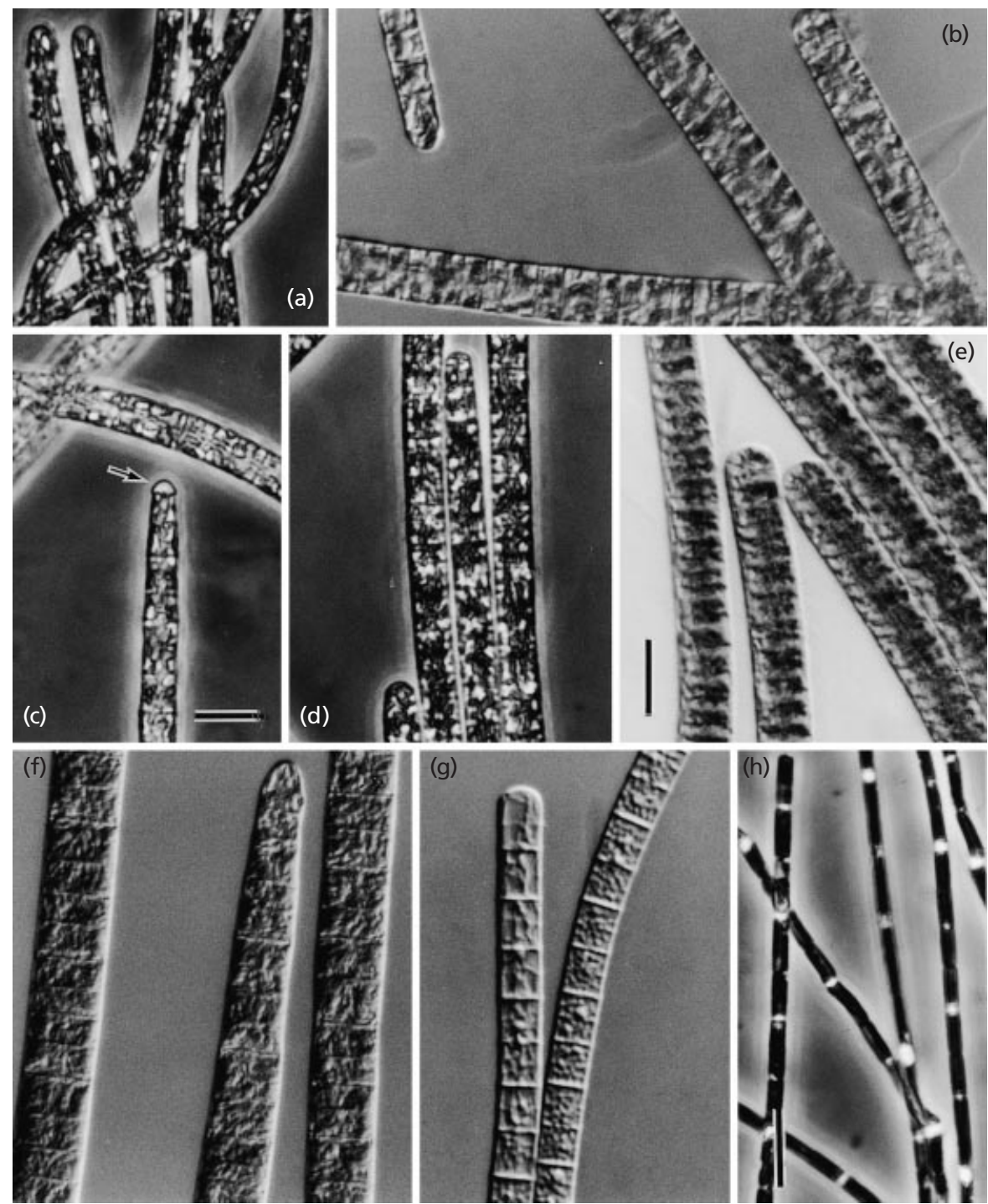

Fig. 6. Light micrographs of Planktothrix agardhii strains CCAP 1459/15 (a) and CCAP 1459/21 (b) (group I-pc), Planktothrix rubescens NIVA CAY 108 (c) (group I-pe), Planktothrix pseudagardhii T1-8-4 (d) (group II), Planktothrix mougeotii TK5-1 (e) (group III), Planktothricoides raciborskii OR1-1 (f) (group IV), Tychonema bourrellyi CCAP 1459/11B (g) (group V) and Limnothrix redekei NIVA CYA 277/1 ${ }^{\top}$ (h) (group VI). Panels (a), (c), (d) and (h) are phase-contrast micrographs; panels (b) and (e-g) are Nomarski micrographs. Strains CCAP 1459/15 (a) and CCAP $1459 / 21$ (b) are respectively representative of group I-pc strains with narrow and wide cells (see Fig. 7). The arrow in (c) indicates a calyptra. Bars, $10 \mu \mathrm{m}$.

salinity tolerance; wide (group III), medium (groups Ipc, I-pe, II and IV) and narrow (groups V and VI).

\section{Morphological observations of each group and subgroup}

With the exception of cell width, most morphological characters were common to strains of group I-pc and II (Fig. 6a, b, d), as outlined below in the descriptions of Planktothrix agardhii (group I-pc strains) and Planktothrix pseudagardhii sp. nov. (group II strains). Cells of group I-pc strains were $2 \cdot 3-9 \cdot 8 \mu \mathrm{m}$ wide and $1 \cdot 2-5 \cdot 3 \mu \mathrm{m}$ long and the ratio of cell length to cell width was $1: 3-1: 1$. The minimum cell width observed was $3 \cdot 0 \pm 0 \cdot 7 \mu \mathrm{m}$ (NIES 205) and the maximum was $8 \cdot 7 \pm 1 \cdot 3 \mu \mathrm{m}$ (CCAP $1459 / 21$; Fig. 6 b). In contrast, the mean and standard deviation for cell length ranged from $2 \cdot 2 \pm 0.5 \mu \mathrm{m}$ (NIVA CYA 91) to $3.5 \pm 1 \cdot 3 \mu \mathrm{m}$ (CCAP 1459/16). Since the standard deviation ranges of strains overlapped continuously (Fig. 7), clear divisions cannot be made among the group I-pc strains on the basis of cell size. Cells of group II strains were $3 \cdot 0-6 \cdot 4 \mu \mathrm{m}$ wide and $1 \cdot 2-4 \cdot 2 \mu \mathrm{m}$ long and the ratio of cell length to cell width was about $1: 3-1: 1$. The range of cell dimensions of group I-pc strains included that of group II strains. Hence, groups I-pc and II could not be distinguished/separated by macroscopic and lightmicroscopic, morphological characters. 


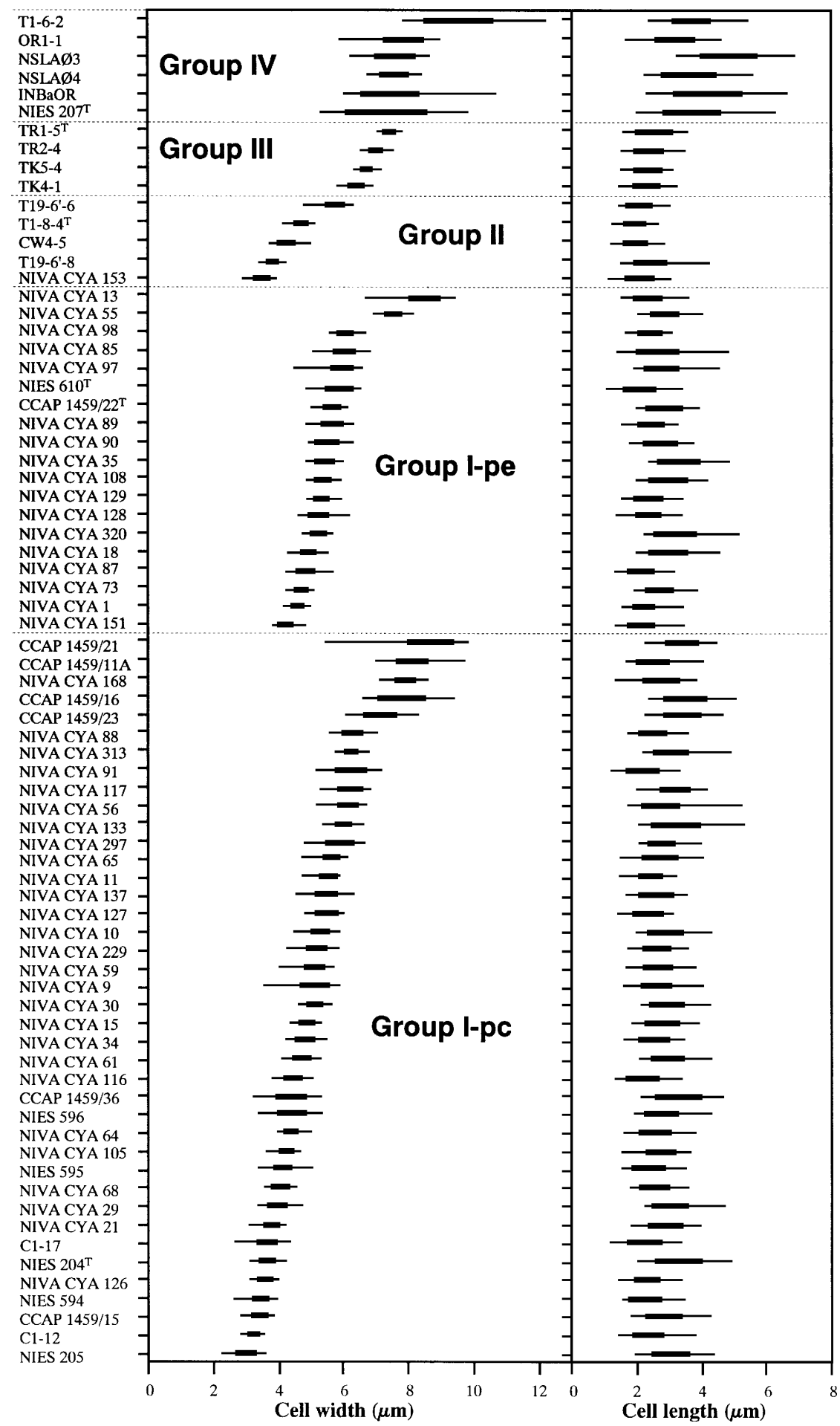

Fig. 7. Cell dimensions of strains of groups I-IV. Groups V and VI, which each include only one strain, were omitted. Narrow lines indicate the range; thick lines indicate the standard deviation.

With the exception of trichome colour, the morphological characters of group I-pe were similar to those of strains of groups I-pc and II (Fig. 6c). Cells of all group I-pe strains were 3.9-9.4 $\mu \mathrm{m}$ wide and $1 \cdot 1-5 \cdot 2 \mu \mathrm{m}$ long and the ratio of cell length to cell width was about 1 :
3-1:1 (Fig. 7). The minimum cell width observed was $4 \cdot 2 \pm 0 \cdot 2 \mu \mathrm{m}$ (NIVA CYA 151) and the maximum was $8 \cdot 6 \pm 0.5 \mu \mathrm{m}$ (NIVA CYA 13). In contrast, the mean and standard deviation of cell length ranged from $2 \cdot 1 \pm 0 \cdot 5 \mu \mathrm{m}\left(\right.$ NIES $610^{\mathrm{T}}$ ) to $3 \cdot 3 \pm 0 \cdot 6 \mu \mathrm{m}$ (NIVA CYA 
35). The standard-deviation ranges for the strains overlapped (Fig. 7), indicating that clear divisions cannot be made among the group I-pe strains on the basis of morphology.

The morphological characters of the four strains of group III (TR1-5 ${ }^{\mathrm{T}}$, TR2-4, TK4-5 and TK5-1) (Fig. 6e) are outlined below in the description of Planktothrix mougeotii. Cells of group III strains were $5.9-7.8 \mu \mathrm{m}$ wide and $1.5-3.6 \mu \mathrm{m}$ long and the ratio of cell length to cell width was about $1: 3-2: 3$. The minimum cell width observed was $6 \cdot 5 \pm 0 \cdot 2 \mu \mathrm{m}$ (TK51) and the maximum was $7 \cdot 5 \pm 0 \cdot 2 \mu \mathrm{m}\left(\mathrm{TR} 1-5^{\mathrm{T}}\right)$. The mean and standard deviation of the smallest and largest cell lengths were respectively $2 \cdot 3 \pm 0 \cdot 4 \mu \mathrm{m}$ (TK5-1) and 2.6 $\pm 0.6 \mu \mathrm{m}\left(\mathrm{TR} 1-5^{\mathrm{T}}\right)$ (Table 3). As the standard-deviation ranges overlapped (Fig. 7), clear divisions cannot be made among these strains on the basis of cell size.

The morphological characters of the six strains of group IV (Fig. 6f) are given below in the description of Planktothricoides raciborskii gen. nov., comb. nov. Cells of the group IV strains were 5.4-12.2 $\mu \mathrm{m}$ wide and $1.7-6.7 \mu \mathrm{m}$ long and the ratio of cell length to cell width was about $2: 7-1: 1$. On occasion, wide sections were observed in a single trichome, in both lab cultures and field samples. The minimum cell width was $7 \cdot 4 \pm 1.2 \mu \mathrm{m}$ (NIES $207^{\mathrm{T}}$ ) and the maximum was $9 \cdot 6 \pm 1.0 \mu \mathrm{m}$ (T1-6-2). The mean and standard deviation of cell length ranged from $3 \cdot 3 \pm 0 \cdot 6 \mu \mathrm{m}(\mathrm{OR} 1-1)$ to $4.9 \pm 0.9 \mu \mathrm{m}$ (NSLAO3). The standard deviation ranges of each strain overlapped (Fig. 7), indicating that clear division cannot be made among these strains on the basis of cell size.

The morphological properties of the group V strain, CCAP $1459 / 11 \mathrm{~B}^{\mathrm{T}}$ (Fig. $6 \mathrm{~g}$ ), and the group VI strain, NIVA CYA $277 / 1^{\mathrm{T}}$ (Fig. $6 \mathrm{~h}$ ), are listed below in the descriptions of Tychonema bourrellyi (group V) and Limnothrix redekei (group VI).

\section{DNA-DNA relatedness between groups I-pc and I-pe}

With the exception of strains belonging to groups I-pc and I-pe, the groups were well characterized genotypically and phenotypically. In contrast, groups I-pc and I-pe had the same 16S rDNA sequences and DNA base composition (Fig. 1, Table 3) but were phenotypically different (PE absent or present). DNA-DNA hybridization experiments were performed to clarify these subgroups further. Labelled DNA derived from the group I-pc strain NIES $204^{\mathrm{T}}$ was hybridized to DNA of group I-pc strains C1-12, CCAP 1459/11A, NIVA CYA 10, NIVA CYA 11, NIVA CYA 21, NIVA CYA 88, NIVA CYA 116, NIVA CYA 126, NIVA CYA 229 and NIVA CYA 313 and their relative binding ratios (RBRs) were respectively $71,73,89,77$, $86,83,92,74,85$ and $80 \%$. In addition, labelled DNA of the group I-pc strain NIES $204^{\mathrm{T}}$ and group I-pe strain CCAP $1459 / 22^{\mathrm{T}}$ (= NIVA CYA $18^{\mathrm{T}}=\mathrm{NIES}$ $610^{\mathrm{T}}$ ) was hybridized to DNA of group I-pe strains
NIVA CYA 35, NIVA CYA 85, NIVA CYA 90, NIVA CYA 98 and NIVA CYA 129. RBRs between NIES $204^{\mathrm{T}}$ and the strains of group I-pe were 54, 49, 53, 44 and $49 \%$ and those between CCAP $1459 / 22^{\mathrm{T}}$ and the other group I-pe strains were 81, 97, 98, 95 and $79 \%$.

\section{DISCUSSION}

\section{Compatibility with the traditional, botanical taxonomy}

The 75 strains of water-bloom-forming species of freshwater, oscillatorioid cyanobacteria in this study were separated into the six phylogenetic groups, I-VI, based on 16S rDNA sequences. Group I was further divided into two groups based on PC/PE composition, which was supported by total genome DNA-DNA hybridization. Strains of groups I-pc and I-pe shared RBRs of more than $70 \%$ within each group but less than $55 \%$ between groups. Since it has been widely accepted that the same species should share more than $70 \%$ DNA-DNA binding (Wayne et al., 1987), the results indicate clearly that these two groups correspond to different taxa. The seven recognized groups were also characterized by genetic and phenotypic properties such as DNA base composition, fatty acid composition, phycobilin pigment composition, chromatic adaptation, growth at different temperatures and salinities and morphology.

Groups I-pc and II corresponded to $O$. agardhii and its intraspecific taxa (Table 4). Elenkin (1949) described five intraspecific taxa in $O$. agardhii (Table 4). These intraspecific taxa seem to be morphological variations within $O$. agardhii, because the 41 strains showed the following common features; (i) trichomes with no or small constrictions at the cross-walls were found in the same strain, (ii) a gelatinous sheath was occasionally observed under unfavourable conditions and (iii) calyptra and attenuation towards the ends of trichomes were variable characters on different trichomes within a single clone. These results agree with the suggestions of Komárek (1958). Furthermore, Skuja (1948) described $O$. agardhii var. isothrix, which is characterized by cell widths of 6-9.5 $\mu \mathrm{m}$ and no attenuation towards the ends of trichomes (Table 4). Later, however, he revised his original description of this intraspecific taxon and concluded that the difference between $O$. agardhii and $O$. agardhii var. isothrix was only cell width, which was respectively $4-6 \mu \mathrm{m}$ and 6-9.5 $\mu \mathrm{m}$ (Skuja, 1956). These differences seem to be clear, but our actual results indicated that it is difficult to define precise morphological criteria to delineate these taxa. The same is true for $O$. agardhii var. suspensa, which was characterized by a cell width of $3.8-4 \mu \mathrm{m}$ (Pringsheim, 1965). In conclusion, on the basis of morphological features, there are no criteria for distinguishing these intraspecific taxa from $O$. agardhii. Furthermore, group II strains could not be separated from strains of group I-pc on phenotypic/ morphological criteria. Hence, group II strains can 
Table 4. Characters of water-bloom-forming Oscillatoria species

Taxa are listed as: 1, O. agardhii Gomont 1892; 2, O. agardhii f. aequicrassa Elenkin 1949; 3, O. agardhii f. gomontii Elenkin 1949; 4, O. agardhii f. moebiusii Elenkin 1949; 5, O. agardhii f. lemmermannii Elenkin 1949; 6, O. agardhii f. wislouchii Elenkin 1949; 7, O. agardhii var. isothrix Skuja 1948; 8, O. agardhii var. suspensa Pringsheim 1965; 9, O. prolifica (Greville) Gomont $1892 ; 10$, O. rubescens D.C. ex Gomont 1892; 11, O. rubescens var. caucasica Schmidle 1897; 12, O. mougeotii Kützing ex Lemmermann 1907; 13, O. raciborskii Woloszynska 1912; 14, O. redekei Van Goor 1918.

\begin{tabular}{|lccccccccccccccc|}
\hline Character & $\mathbf{1}$ & $\mathbf{2}$ & $\mathbf{3}$ & $\mathbf{4}$ & $\mathbf{5}$ & $\mathbf{6}$ & $\mathbf{7}$ & $\mathbf{8}$ & $\mathbf{9}$ & $\mathbf{1 0}$ & $\mathbf{1 1}$ & $\mathbf{1 2}$ & $\mathbf{1 3}$ & $\mathbf{1 4}$ \\
\hline Cell width $(\mu \mathrm{m})$ & $4-6$ & $4-6$ & $4-6$ & $3-4$ & $4-6$ & $4-6$ & $6-9 \cdot 5$ & $3 \cdot 8-4$ & $2 \cdot 2-5 \cdot 5$ & $6-8$ & $8-9$ & $5 \cdot 5-7 \cdot 5$ & $8-9$ & $1 \cdot 3-2 \cdot 3$ \\
Length:width & $1: 2$ & $1: 2$ & $1: 2$ & $1: 2$ & $1: 2$ & $1: 2$ & $1: 3-3: 4$ & $1: 2-1: 1$ & $1: 1$ & $1: 3-1: 2$ & $1: 2-1: 1$ & $1: 2$ & $1: 2$ & $3: 1-8: 1$ \\
Apical cell type* & $\mathrm{V}$ & $\mathrm{R}$ & $\mathrm{V}$ & $\mathrm{V}$ & $\mathrm{V}$ & $\mathrm{R}$ & $\mathrm{C}$ & $\mathrm{C}$ & $\mathrm{CC}$ & $\mathrm{CC}$ & $\mathrm{C}$ & $\mathrm{BR}$ & $\mathrm{TB}$ & $\mathrm{R}$ & - \\
Calyptra & + & - & + & + & + & - & - & + & + & + & + & - & - & - \\
Gelatinous sheath & - & - & - & - & + & - & - & - & - & - & - & - & - & - \\
Attenuation at the end & + & - & + & + & + & + & - & + & + & + & + & - & + & - \\
Trichome colour & PBG & PBG & PBG & PBG & PBG & PBG & PBG & PBG & RP & RP & G & DBG & YG & PBG \\
\hline
\end{tabular}

* BR, Broadly rounded; C, conical; CC, conical, capitate; R, rounded; TB, tapered, bent; v, variable.

$\dagger$ DBG, Dull blue-green; G, green; PBG, pale blue-green; RP, reddish purple; YG, yellow-green.

only be identified as $O$. agardhii under the traditional, botanical taxonomy.

The group I-pe strains were identified as $O$. rubescens. These strains had previously been named as $O$. agardhii, $O$. agardhii var., $O$. rubescens and $O$. rubescens var. in the NIVA and CCAP collections (Table 1). According to the original descriptions of $O$. agardhii and O. rubescens, except for trichome colour, differences between these species were restricted to cell width, which is respectively $4-6 \mu \mathrm{m}$ and $6-8 \mu \mathrm{m}$. Because of the apparent instability of trichome colour, there has been a tendency to use cell width rather than trichome colour as the key diagnostic character for classification (e.g. Elenkin, 1949). Cell-size measurements in the present study indicated that cell width does not distinguish these species. However, for group I-pe strains and group I-pc and II strains, trichome colours were stable and corresponded to qualitative and quantitative differences in phycobilin pigments. The other gas-vacuolated, reddish-brown-coloured Oscillatoria species is Oscillatoria prolifica (Greville) Gomont (Table 4). Cells of this species are $2 \cdot 2-5 \mu \mathrm{m}$ wide and 4-6 $\mu \mathrm{m}$ long and cells are as long or longer than they are wide. The apical cells are capitate and have calyptra. These characters do not concur with the narrow width of the group I-pe strains.

Group III strains were identified as $O$. mougeotii Kützing ex Lemmermann. There is considerable confusion regarding the taxonomy and description of $O$. mougeotii. The first description of $O$. mougeotii was made by Bory (1827) (cited by Gomont, 1892). Later, Kützing (1849) published a more detailed description with figures, detailing that $O$. mougeotii has reddish purple trichomes, many small granules and a cell width of 6-7 $\mu \mathrm{m}$. In the first comprehensive taxonomy of the Oscillatoriales, published by Gomont (1892), which is approved as a starting point of Oscillatoriales in the International Code of Botanical Nomenclature, the type specimen of $O$. mougeotii Bory was described as the same as Oscillatoria formosa Bory and $O$. mougeotii Bory was therefore described as a synonym of $O$. formosa Bory. In addition, Gomont (1892) did not comment on O. mougeotii Kützing (1849). Therefore, it is possible to interpret that there was no valid $O$. mougeotii at the taxonomic starting point of the Oscillatoriales, although Gomont (1892) failed to include $O$. mougeotii Bory in the rejected species list (species excludendae). Accordingly, the description of O. mougeotii after Gomont (1892) could be recognized as valid. In 1907, Lemmermann and Forti independently described $O$. mongeotii Kützing. The description of Lemmermann (1907) differed from that of $O$. mougeotii Bory as follows. The cell mass is dark or dull blue-green, cells are 5.5-7.5 wide and 2-3 $\mu \mathrm{m}$ long and the trichome breaks easily. Trichomes are straight or slightly curved and not constricted at the cross-walls. The apical cells are broadly rounded and have no calyptra. In the early stages of cell growth, trichomes attach to substrates and then float freely. These characteristics agreed well with those of the strains in this study. In contrast, the description of $O$. mougeotii by Forti (1907) is the same as that of Kützing (1849) except that the cell width is $7.5 \mu \mathrm{m}$, and he also reported that $O$. mougeotii was similar to $O$. rubescens. The largest difference between Lemmermann's description of $O$. mougeotii and Forti's is the trichome colour; the former gives dark blue-green and the latter gives reddish purple. Lemmermann's paper was combined with other papers and republished in 1910. This republished paper was widely distributed and has been cited as 'Lemmermann (1910)' [here, we refer to this paper as Lemmermann (1907 or 1910)]. As a result, Lemmermann's description has understandably been misunderstood to have been published later than Forti's. This situation has probably given rise to confusion among later researchers. Geitler (1932) and Elenkin (1949) described $O$. mougeotii Kützing and $O$. 
mougeotii Kützing ex Forti, respectively, but their descriptions were similar to those of Lemmermann (1907 or 1910). Furthermore, Elenkin (1949) added that the trichome colour was reddish purple in some cases, in accordance with Forti's description. More recently, Anagnostidis et al. (1985) emphasized that $O$. mougeotii was similar to $O$. agardhii var. isothrix Skuja. Later, when Anagnostidis \& Komárek (1988) established the new genus Planktothrix for gas-vacuolate Oscillatoria species, O. mougeotii was changed to 'Planktothrix mougeotii (Bory ex Gomont) Anagnostidis \& Komárek'. However, their revision incurred the following contradiction in nomenclature; ' $P$. mougeotii (Bory ex Gomont) Anagnostidis \& Komárek', which has gas vacuoles and is planktonic, is a new combination of $O$. mougeotii Bory ex Gomont, which is the same specimen as that of $O$. formosa Bory ex Gomont, which has no gas vacuoles and is benthic. Thus, the new combination caused more chaos in the taxonomy and nomenclature of $O$. mougeotii and related species. In addition, although Anagnostidis \& Komárek (1988) treated O. agardhii var. isothrix Skuja as a synonym of 'Planktothrix mougeotii', O. agardhii var. isothrix should be included within the morphological variations displayed by $O$. agardhii detailed above.

Since it was observed repeatedly in our study that strains of $O$. rubescens have characteristics close to those of the reddish-purple-coloured $O$. mougeotii described by Kützing (1849) and Forti (1907), it is thought that granulated trichomes of $O$. rubescens were described as $O$. mougeotii. This view is supported by the fact that reddish-purple-coloured $O$. mougeotii that is clearly different from $O$. rubescens has never been isolated or reported. In contrast, there are cultures that are identified as dark blue-green-coloured O. mougeotii, as described by Lemmermann (1907). $O$. mougeotii Kützing ex Forti would be better treated as a synonym of $O$. rubescens.

The morphological characters of the group IV strains corresponded to the original description of $O$. raciborskii, isolated from ponds on the island of Java, Indonesia (Woloszynska, 1912). Although $O$. raciborskii was reported to have very long trichomes in the original description, this should not be regarded as a taxonomic characteristic, because the length of trichomes changes easily under different conditions and at different growth stages. In fact, the trichomes tended to be shorter in old cultures (data not shown).

The group V strain, CCAP $1459 / 11 \mathrm{~B}^{\mathrm{T}}$, had previously been identified as $O$. agardhii in the CCAP (Table 1). However, morphologically, the strain corresponds to the original description of Oscillatoria bourrellyi Lund (1955), which has been revised as Tychonema bourrellyi (Skulberg \& Skulberg, 1991). Although O. bourrellyi was reported to have calyptra in the original description, the strain in this study had no calyptra. However, this diagnostic feature may be variable, as the presence or absence of calyptra is due to the developmental stage of individual filaments in Lyngbya hieronymusii var. hieronymusii and the character is variable under different environmental conditions (Suda et al., 1998). Based on the above considerations, the group V strain was identified as $O$. bourrellyi.

The group VI strain, NIVA CYA $277 / 1^{\mathrm{T}}$, which is listed as $O$. redekei in the NIVA collection (Skulberg, 1990), has features quite different from the other water-bloom-forming Oscillatoria. They are characterized by having no attenuation towards the ends of trichomes, narrow, long cells, rounded apical cells and two large, polar gas vesicles. The only difference between the original description of $O$. redekei and the present strain is colour. However, Meffert (1987) reported that $O$. redekei showed complementary chromatic adaptation, which was also demonstrated in the present study.

\section{Revision of the taxonomy of water-bloom-forming oscillatorioids}

From the above discussion, it is proposed that groups I-pc and II correspond to $O$. agardhii, group I-pe to $O$. rubescens, group III to $O$. mougeotii, group IV to $O$. raciborskii, group V to $O$. bourrellyi and group VI to $O$. redekei. In this section, we outline the taxonomic relationships between the seven groups based on results obtained in this study and give new or emended descriptions of each taxon recognized.

In order to ascertain the taxonomic position of the seven groups recognized by the present study, it was necessary to define the phylogenetic position of the type species of the genus Oscillatoria (O. princeps Gomont). However, to date, the $16 \mathrm{~S}$ rDNA sequence of this species has not been published. The morphology of $O$. princeps NIVA CYA 150 corresponded well with original description of Gomont (1892), except for trichome colour. This strain was dark brown-green, rather than blue-green as in the original description of O. princeps (Gomont, 1892). However, this difference was not considered phylogenetically significant enough to prevent the use of sequence data for $O$. princeps NIVA CYA 150 as that of the type species of the genus Oscillatoria (Gomont, 1892), because similar 16S rDNA sequences have previously been reported in different-coloured Merismopedia strains (Palinska et al., 1996) and Microcystis strains (Otsuka et al., 1998). From the phylogenetic tree based on 16S rDNA sequences, it was found that $O$. princeps Gomont (1892) was located as a sister group of Scytonema hoffmanii PCC 7110 and was not related to groups I-VI. This suggested that the bloom-forming oscillatorioid species should not be listed under the genus name Oscillatoria and that their generic name should be changed, as proposed previously by Anagnostidis \& Komárek (1988), Meffert (1988) and Skulberg \& Skulberg (1991) on the basis of purely phenotypic characteristics.

The similarity of the 1361-bp 16S rDNA sequences was $95 \cdot 4-96.7 \%$ between groups I and II, 95.9-96.8\% between groups I and III and $96 \cdot 4-96 \cdot 8 \%$ between 


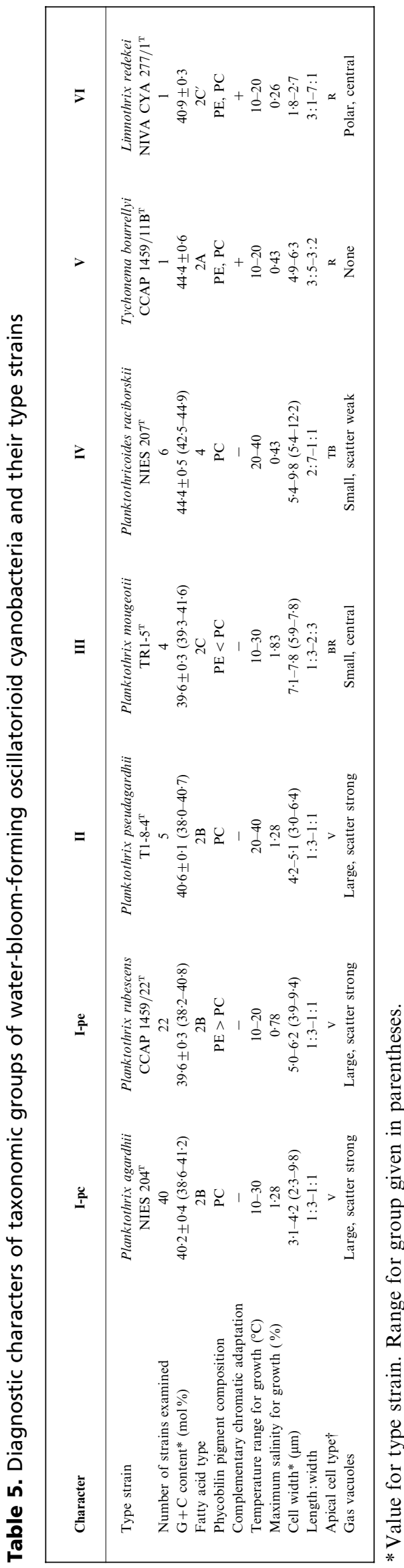

groups II and III. These values are at the congeneric level according to Devereux et al. (1990). In addition, the fatty acid compositions and $\mathrm{G}+\mathrm{C}$ contents of groups I-III were similar and they did not undergo complementary chromatic adaptation. Anagnostidis \& Komárek (1988) have renamed gas-vacuolated Oscillatoria as genus Planktothrix, with the type species Planktothrix agardhii. Our results support the appropriateness of classifying the water-bloomforming, gas-vacuolated Oscillatoria species in other genera. Group I was further divided into two subgroups, groups I-pc and I-pe, by phycobilin pigment composition. These groups demonstrated little difference in growth temperature and salinity tolerance. However, DNA-DNA hybridization revealed that groups I-pc and I-pe were independent species. Combining these data and the traditional taxonomic conclusions outlined above, it is appropriate that strains of group I-pc should be treated as Planktothrix agardhii and those of group I-pe as Planktothrix rubescens (Table 5). As detailed above, we propose to treat $O$. mougeotii Kützing ex Forti as a synonym of Planktothrix rubescens $(=O$. rubescens).

Group II strains were identical to group I-pc in morphology, fatty acid composition, $\mathrm{G}+\mathrm{C}$ content and phycobilin pigment, but showed a clear difference in growth temperature range and, moreover, these two groups can be distinguished clearly from each other in phylogenetic trees. Hence, it is quite reasonable that group II should be treated as a novel species, and we propose the name Planktothrix pseudagardhii sp. nov. for this taxon because strains are similar in morphology to Planktothrix agardhii. It is appropriate that strains of group III, which were morphologically compatible with $O$. mougeotii Kützing ex Lemmermann (different from O. mougeotii Bory ex Gomont), should be treated as a species within the genus Planktothrix.

We propose to reject 'Planktothrix mougeotii (Bory ex Gomont) Anagnostidis et Komárek' for the following reasons (detailed above): (i) O. mougeotii Bory ex Gomont was changed to 'Planktothrix mougeotii (Bory ex Gomont) Anagnostidis et Komárek'; (ii) $O$. mougeotii Bory ex Gomont is clearly described as a synonym of $O$. formosa Bory (Gomont, 1892); and (iii) $O$. formosa Bory was described as having no gas vacuoles and as a benthic species, which is not appropriate for a member of the genus Planktothrix.

We also propose to give the name Planktothrix mougeotii to group III in this study, since the group III strains were identified as $O$. mougeotii Kützing ex Lemmermann, which is regarded as a valid name (as detailed above) and has been shown to be appropriate as a species in the genus Planktothrix.

The strains of group IV, which were morphologically similar to $O$. raciborskii, formed an independent phylogenetic cluster separated from the cluster of groups I-III, which were assigned to Planktothrix. This group showed less than $89.7 \%$ similarity of $16 \mathrm{~S}$ 
rDNA sequence to the other groups and the $O$. princeps and $L$. hieronymusii var. hieronymusii strains. According to Devereux et al. (1990), less than 94.6\% similarity corresponds to the level of different genera. In addition, group IV was distinguished by fatty acid composition and $\mathrm{G}+\mathrm{C}$ content from the Planktothrix groups, and we propose the name Planktothricoides raciborskii gen. nov., comb. nov. for group IV $(O$. raciborskii).

Group V, strain CCAP $1459 / 11 \mathrm{~B}^{\mathrm{T}}$, identified as $O$. bourrellyi, has been renamed Tychonema bourrellyi by Anagnostidis \& Komárek (1988) and Skulberg \& Skulberg (1991). From the phylogenetic data obtained from 16S rRNA gene sequence analysis of this strain, it was found that this strain forms a cluster independent of the other groups and the type species of Oscillatoria $(O$. princeps). This strongly supports the view proposed by the above authors. Hence, it is appropriate that the group V $(O$. bourrellyi) should be treated as Tychonema bourrellyi.

Group VI, strain NIVA CYA $277 / 1^{\mathrm{T}}$, identified as $O$. redekei, has been renamed Limnothrix redekei by Meffert (1988). Phylogenetic trees revealed that the species was very far from $O$. princeps and the other groups. This species was further characterized by the ability to undergo complementary chromatic adaptation, fatty acid composition, growth temperature and salinity tolerance. Hence, it is appropriate that group VI (O. redekei) should be treated as Limnothrix redekei.

Phylogenetic analyses based on 16S rDNA sequences could draw distinctions among five taxa, Planktothrix pseudagardhii, Planktothrix mougeotii, Planktothricoides raciborskii, Tychonema bourrellyi and Limnothrix redekei. However, Planktothrix agardhii and Planktothrix rubescens could not be separated by 16S rDNA sequence analysis, morphology, fatty acid composition or $\mathrm{G}+\mathrm{C}$ content (Table 5), but were distinguishable by phycobilin pigment composition, growth at different temperatures and salinities (Table 5) and DNA-DNA hybridization. These observations suggest that their differentiation may be a relatively recent event. Use of $16 \mathrm{~S}$ rDNA sequence analysis is a powerful tool for taxonomy; however, characterization based on the sequence alone is not enough for classification of species of some organisms, especially for closely related species.

Planktothrix agardhii and Planktothrix pseudagardhii were well defined by $16 \mathrm{~S}$ rDNA sequence analysis. They shared the same characters of fatty acid composition, phycobilin pigment, $\mathrm{G}+\mathrm{C}$ content and morphology (Table 5). This suggests that their speciation may have occurred prior to that between Planktothrix agardhii and Planktothrix rubescens. Without doubt, a polyphasic approach will be needed to solve the confusion facing cyanobacteria taxonomy, as well as modern bacterial classification suggested by Vandamme et al. (1996).

\section{Emended description of Planktothrix Anagnostidis \& Komárek 1988}

Water-bloom-forming, non-heterocystous and filamentous cyanobacteria bearing many gas vacuoles. Trichomes are straight or slightly curved, attenuated or not toward the ends and not surrounded by a clear sheath. Cross-walls are constricted or unconstricted and usually not granulated. DNA $\mathrm{G}+\mathrm{C}$ content is about $40 \mathrm{~mol} \%$. Fatty acid composition is type 2 . The type species is Planktothrix agardhii (Anagnostidis \& Komárek 1988).

\section{Emended description of Planktothrix agardhii (Gomont) Anagnostidis \& Komárek 1988}

\author{
Basonym: Oscillatoria agardhii Gomont 1892.
}

Synonyms: Oscillatoria agardhii f. aequicrassa Elenkin 1949; Oscillatoria agardhii f. moebiusii Elenkin 1949; Oscillatoria agardhii f. lemmermannii Elenkin 1949; Oscillatoria agardhii f. wislouchii Elenkin 1949; Oscillatoria agardhii f. gomontii Elenkin 1949; Oscillatoria agardhii var. isothrix Skuja 1948; Oscillatoria agardhii var. suspensa Pringsheim 1965; Planktothrix mougeotii (Bory ex Gomont) Anagnostidis et Komárek 1988.

Micrographs are shown in Fig. 6(a, b). Trichomes are pale blue-green or yellow-green. Trichomes are solitary and float, although in the early stages of cultivation they sometimes become entangled and sink to the bottom of the culture tube; however, they never attach there. They are straight or slightly curved, usually attenuated towards the ends and not surrounded by a sheath under conditions favourable for growth. Under unfavourable conditions (e.g. nutrient depletion, heavy contamination by heterotrophic bacteria), trichomes may be surrounded by a gelatinous sheath and may attach to the walls of the culture tube. Crosswalls are slightly constricted or unconstricted and not granulated. Gas vacuoles are relatively large and scattered at the periphery of the cells. Apical cells show variable shapes: rounded, tapered, bluntly conical, occasionally capitate, with or without calyptra. Cell width is $2 \cdot 3-9 \cdot 8 \mu \mathrm{m}$, cell length is $1 \cdot 3-5 \cdot 1 \mu \mathrm{m}$ and the ratio of cell length to width is about $1: 3-1: 1$. PE is absent. Not capable of complementary chromatic adaptation. Fatty acid composition is type 2B. DNA $\mathrm{G}+\mathrm{C}$ content is about $40 \mathrm{~mol} \%$. Growth temperature range is $10-30{ }^{\circ} \mathrm{C}$. Salinity tolerance for growth is up to $0.78 \%$. The type strain is strain NIES $204^{\mathrm{T}}$ (= CCAP $\left.1460 / 5^{\mathrm{T}}\right)($ Table 5).

\section{Emended description of Planktothrix rubescens (D.C. ex Gomont) Anagnostidis et Komárek 1988}

Basonym: Oscillatoria rubescens D.C. ex Gomont 1892.

Synonym: Oscillatoria mougeotii Kützing ex Forti 1907. 
A micrograph is shown in Fig. 6(c). Trichomes are reddish purple or reddish brown. Trichomes are solitary and float, although sometimes they become entangled and sink to the bottom of the culture tube; however, they never attach there. Trichomes are straight or slightly curved and attenuated or not towards the ends. Cross-walls are slightly constricted or not constricted and not granulated. Gas vacuoles are relatively large and scattered at the periphery of the cells. Apical cells show variable shapes: rounded, tapered, bluntly conical, rarely capitate, with or without calyptra. The cell width is $3 \cdot 9-9 \cdot 4 \mu \mathrm{m}$, cell length is $1 \cdot 1-4.9 \mu \mathrm{m}$ and the ratio of cell length to cell width is about $1: 3-1: 1$. A large amount of $\mathrm{PE}$ is present with a high PE:PC ratio. Not capable of complementary chromatic adaptation. Fatty acid composition is type $2 \mathrm{~B}$. DNA $\mathrm{G}+\mathrm{C}$ content is about $40 \mathrm{~mol} \%$. Growth temperature range is $10-20^{\circ} \mathrm{C}$. Salinity up to $0.43 \%$ is tolerated for growth. The presence of PE is a principal distinguishing diagnostic character from $P$. agardhii. The type strain is strain CCAP $1459 / 22^{\mathrm{T}}\left(=\right.$ NIVA CYA $18^{\mathrm{T}}=$ NIES $\left.610^{\mathrm{T}}\right)$ (Table 5).

\section{Description of Planktothrix pseudagardhii sp. nov. Suda \& Watanabe}

Planktothrix pseudagardhii [pseu.da.gar'dhi.i. Gr. adj. pseudos false, N.L. fem. n. pseudagardhii false agardhii, referring to Planktothrix agardhii (Gomont) Anagnostidis et Komárek].

A micrograph is shown in Fig. 6(d). Trichomes are pale blue-green or yellow-green. Trichomes are solitary and they float, they sometimes become entangled and sink to the bottom of culture tubes, but they never attach there. They are straight or slightly curved, sometimes attenuated towards the ends and not surrounded by sheath under conditions favourable for growth. Cross-walls may be slightly constricted or not constricted and not granulated. Gas vesicles are relatively large and scattered at the periphery of the cells. Apical cells show variable shapes such as rounded, tapered, bluntly conical, occasionally capitate, with and without calyptra. Cell dimensions are $3 \cdot 0-6 \cdot 4 \mu \mathrm{m}$ wide, $1 \cdot 2-4 \cdot 2 \mu \mathrm{m}$ long and the ratio of cell length to width is about $1: 3-1: 1$. PE is absent. Not capable of complementary chromatic adaptation. Fatty acid composition is type $2 \mathrm{~B}$. DNA G $+\mathrm{C}$ content is about $40 \mathrm{~mol} \%$. Growth temperature range is $20-30{ }^{\circ} \mathrm{C}$. Salinity up to $0.78 \%$ is tolerated for growth. $16 \mathrm{~S}$ rDNA sequence is the only distinguishing character between $P$. agardhii and this species. The type strain is strain $\mathrm{T} 1-8-4^{\mathrm{T}}\left(=\mathrm{NIES} 845^{\mathrm{T}}=\mathrm{CCAP} 1460 / 7^{\mathrm{T}}\right)$ (Table 5).

\section{Description of Planktothrix mougeotii (Kützing ex Lemmermann) comb. nov. non (Bory ex Gomont) Anagnostidis et Komárek 1988}

Basonym: Oscillatoria mougeotii Kützing ex Lemmermann 1907, 1910.
A micrograph is shown in Fig. 6(e). Trichomes are dark blue-green to olive-green. Trichomes are initially attached to the bottom or side wall of culture tubes and then float in the upper to middle layer of the culture medium. Entangled trichomes sometimes cover the entire surface of the medium. Usually, the trichomes are straight, occasionally twisted and not attenuated towards the ends. Cross-walls are slightly constricted. Gas vacuoles are small and cluster in the equatorial part of the cells and they rarely rupture on placing a microscope cover slip on a drop of culture. Apical cells are broadly rounded and have no calyptra. Cell width is $5.9-7 \cdot 8 \mu \mathrm{m}$, cell length is $1.5-3.6 \mu \mathrm{m}$ and the ratio of cell length to cell width is about $1: 3-2: 3$. A small amount of PE is present, with a low PE:PC ratio. Not capable of complementary chromatic adaptation. Fatty acid composition is type $2 \mathrm{C}$. DNA G $+\mathrm{C}$ content is about $40 \mathrm{~mol} \%$. Growth temperature range is $20-30{ }^{\circ} \mathrm{C}$. Salinity up to $1.28 \%$ is tolerated for growth. The type strain is strain TR $1-5^{\mathrm{T}}\left(=\mathrm{NIES} 844^{\mathrm{T}}=\right.$ CCAP $1460 / 6^{\mathrm{T}}$ ) (Table 5).

\section{Description of Planktothricoides gen. nov. Suda \& Watanabe}

Planktothricoides (Plank.to.thric.oi'des. N.L. n. Planktothrix a genus of cyanobacteria; Gr. comp. oides resembling; N.L. fem. n. Planktothricoides resembling Planktothrix Anagnostidis et Komárek).

Trichomes are solitary, float and are generally straight or slightly bent near the apex and attenuated towards the ends. Occasionally, a very thin, clear sheath is observed. Cross-walls are slightly constricted or not constricted and not granulated. Many small gas vacuoles are scattered at the periphery of the cells and they are easily ruptured during observation with a light microscope when a cover slip is placed on a drop of culture. Has no PE and no capacity to undergo complementary chromatic adaptation. Fatty acid composition is type 4. DNA $\mathrm{G}+\mathrm{C}$ content is about $44 \mathrm{~mol} \%$. Forms a phylogenetic cluster independent from Planktothrix on the basis of 16S rDNA sequence analysis. The type species is Planktothricoides raciborskii.

\section{Description of Planktothricoides raciborskii comb. nov.}

Basonyms: Planktothrix raciborskii (Woloszynska) Anagnostidis et Komárek 1988; Oscillatoria raciborskii Woloszynska 1912.

A micrograph is shown in Fig. 6(f). In addition to the properties listed in the genus description, the following properties are observed. Trichomes are pale blue-green or yellow-green. Apical cells are rounded, more or less tapered, bent but not pointed, bluntly conical and have no calyptra. Cell width is $5 \cdot 4-2 \cdot 2 \mu \mathrm{m}$, cell length is $1 \cdot 7-6.7 \mu \mathrm{m}$ and the ratio of cell length to cell width is 2 : $7-1: 1$. On occasion, thick sections are found in a single trichome in both lab cultures and field samples. 
Growth temperature range is $20-30{ }^{\circ} \mathrm{C}$; some strains grow at $40{ }^{\circ} \mathrm{C}$. Salinity up to $0.78 \%$ is tolerated for growth. The type strain is strain NIES $207^{\mathrm{T}}$ (= CCAP $\left.1465 / 1^{\mathrm{T}}\right)($ Table 5).

\section{Emended description of Tychonema bourrellyi (Lund) Anagnostidis \& Komárek 1988}

Basonym: Oscillatoria bourrellyi Lund 1955.

Synonyms: Oscillatoria bornetii f. tenuis Skuja 1930; Tychonema tenue (Skuja) Anagnostidis et Komárek 1988.

A micrograph is shown in Fig. 6(g). Trichomes are grey to greyish-brown under normal daylight. Trichomes are solitary or sometimes become entangled and sink to the bottom of the culture tubes, but never attach there. They are straight or slightly attenuated toward their ends. Cross-walls are not constricted and not granulated. Apical cells are rounded, not capitate and occasionally have calyptra. Cells have keritomized chromatoplasm (Geitler, 1932). Cells are 4.9-6.3 $\mu \mathrm{m}$ wide and $3 \cdot 2-8 \cdot 0 \mu \mathrm{m}$ long and the ratio of cell length to cell width is approximately $3: 5-3: 2$. PE is present. Capable of complementary chromatic adaptation, which causes a change to reddish-brown cell colour under green light; cell colour does not change significantly under red light. Fatty acid composition is type $2 \mathrm{~A}$. DNA $\mathrm{G}+\mathrm{C}$ content is about $44 \mathrm{~mol} \%$. Growth temperature range is $10-20{ }^{\circ} \mathrm{C}$. Salinity up to $0.43 \%$ is tolerated for growth. The type strain is strain CCAP $1459 / 11 \mathrm{~B}^{\mathrm{T}}\left(=\right.$ NIES $\left.846^{\mathrm{T}}\right)$ (Table 5).

\section{Emended description of Limnothrix redekei (Van Goor) Meffert 1988}

\section{Basonym: Oscillatoria redekei Van Goor 1918.}

A micrograph is shown in Fig. 6(h). The trichome mass is brownish-green to reddish-brown under normal daylight, but the colour of individual trichomes is not recognizable because of their slenderness. Trichomes are solitary or sometimes become entangled and sink to the bottom of the culture tubes, but never attach there. They are straight and not attenuated toward their ends. Cross-walls are not constricted and not granulated. Apical cells are rounded, not capitate and they have no calyptra. Two large gas vacuoles are distributed at the poles of the cells and occasionally in the centre of the cells. Vacuoles are rarely punctured on placing a microscope cover slip on a drop of culture. Cells are $1 \cdot 8-2.7 \mu \mathrm{m}$ wide and $5 \cdot 4-14.3 \mu \mathrm{m}$ long and the ratio of cell length to cell width is approximately $3: 1-7: 1$. PE is present, with a high PE: $\mathrm{PC}$ ratio under normal daylight conditions. Capable of complementary chromatic adaptation, which causes a change to pale blue-green cell colour with a large amount of PC under red light and to reddish-brown cell-mass colour with a large amount of PE under green light. Fatty acid composition is type $2 \mathrm{C}^{\prime}$. DNA $\mathrm{G}+\mathrm{C}$ content is about $41 \mathrm{~mol} \%$. Growth temperature range is $10-20{ }^{\circ} \mathrm{C}$. Salinity up to $0.26 \%$ is tolerated for growth. The type strain is strain NIVA CYA $277 / 1^{\mathrm{T}}$ $\left(=\right.$ NIES $\left.847^{\mathrm{T}}\right)($ Table 5$)$.

\section{ACKNOWLEDGEMENTS}

The authors wish to thank Dr Masayuki Watanabe (The National Science Museum) for his helpful advice and the loan of important taxonomic literature, Professor Jiri Komárek (Czech Republic) for his valuable suggestions and constructive discussions, Dr Renhui Li (Wright State University, OH, USA) for providing cyanobacterial strains, Drs Annet Hehmann and A. Andray Gontcharov (National Institute for Environmental Studies) for translation of German and Russian literature, respectively, Dr Akio Murakami (Kobe University) for demonstrating the preparation and measurement of phycobilin pigments, Dr Akira Yokota (University of Tokyo) for demonstrating the preparation and measurement of DNA base composition, Dr Kenichiro Suzuki (Institute of Physical and Chemical Research, Japan) for preparation and measurement of DNA relatedness, Dr Hideaki Miyashita (Tokyo University of Agriculture and Technology) for valuable information and suggestions, Dr Etsuko Aoki (National Institute for Environmental Studies) for helpful suggestions on DNA sequence and Ms Sachiko Dobashi (Marine Biotechnology Institute, Kamaishi Laboratories) for DNA sequencing. This work was supported financially by the Science and Technology Agency, Japan.

\section{REFERENCES}

Anagnostidis, K. \& Komárek, J. (1988). Modern approach to the classification system of cyanophytes. 3 - Oscillatoriales. Arch Hydrobiol Suppl 80 (Algol Stud 50-53), 327-472.

Anagnostidis, K., Overbeck, J. \& Danielidis, D. (1985). Oscillatoria cf. agardhii var. isothrix Skuja from the lakes of Amvrakia and Trichonis, Greece. A taxonomic consideration. Arch Hydrobiol 104, 205-217.

Bourrelly, P. (1985). Les Algues d'eau Douce. III, 2nd edn. Paris: N. Boubée \& Cie.

Castenholz, R. W. \& Waterbury, J. B. (1989). Group I. Cyanobacteria. Preface. In Bergey's Manual of Systematic Bacteriology, vol. 3, pp. 1710-1727. Edited by J. T. Staley, M. P. Bryant, N. Pfennig \& J. G. Holt. Baltimore: Williams \& Wilkins.

Desikachary, T. V. (1959). Cyanophyta. ICAR Monographs on Algae. New Delhi: Indian Council of Agricultural Research.

Devereux, R., He, S. H., Doyle, C. L., Orkland, S., Stahl, D. A., LeGall, J. \& Whitman, W. B. (1990). Diversity and origin of Desulfovibrio species: phylogenetic definition of a family. $J$ Bacteriol 172, 3609-3619.

Elenkin, A. A. (1949). Monographia algarum cyanophycearum aquidulcium et terrestrium in finibus URSS inventarum [Sinezelenye vodorosli $S S S R]$, Pars specialis (Systematica) Fasc. II. Moscow \& Leningrad: Izd. Acad. Nauk. SSSR.

Ezaki, T., Hashimoto, Y. \& Yabuuchi, E. (1989). Fluorometric deoxyribonucleic acid-deoxyribonucleic acid hybridization in microdilution wells as an alternative to membrane filter hybridization in which radioisotopes are used to determine genetic relatedness among bacterial strains. Int J Syst Bacteriol 39, 224-229.

Forti, A. (1907). Myxophyceae. In Sylloge Algarum Onmium. Edited by De Toni. Padua.

Geitler, L. (1932). Cyanophyceae. In Rabenhorst's Kryptogamenflora, vol. 14, pp. 1-1196. Leipzig: Akademie Verlagsges.

Gomont, M. M. (1892). Monographie des Oscillariées (Nostocacées homocystées). Ann Sci Nat Bot Ser 7 15, 263-368; 16, 91-264.

Hamamoto, M. \& Nakase, T. (1995). Ballistosporous yeasts found on the surface of plant materials collected in New Zealand. 1. Six new 
species in the genus Sporobolomyces. Antonie van Leeuwenhoek 67, 151-171.

Hoshaw, R. \& Rosowski, J. R. (1973). Methods for microscopic algae. In Handbook of Phycological Methods. Culture Methods and Growth Measurements, pp. 53-68. Edited by J. R. Stein. London: Cambridge University Press.

Kenyon, C. N. (1972). Fatty acid composition of unicellular strains of blue-green algae. $J$ Bacteriol 109, 827-834.

Kenyon, C. N., Rippka, R. \& Stanier, R. Y. (1972). Fatty acid composition and physiological properties of some filamentous bluegreen algae. Arch Mikrobiol 83, 216-236.

Komárek, J. (1958). Die taxonomische Revision der planktischen Blaualgen der Tschechoslowakei. In Algologische Studien, pp. 10-206. Edited by J. Komárek \& H. Ettl. Prague: Naklad CSAV.

Kützing, T. F. (1849). Species Algarum. Leipzig: F. A. Brockhaus. Lemmermann, E. (1907 or 1910). Algen I. (Shizophyceen, Flagellaten, Peridineen). In Kryptogamenflora der Mark Brandenburg, vol. 3.

Li, R., Yokota, A., Sugiyama, J., Watanabe, M., Hiroki, M. \& Watanabe, M. M. (1998). Chemotaxonomy of planktonic cyanobacteria based on non-polar and 3-hydroxy fatty acid composition. Phycol Res 46, 21-28.

Lund, J. W. G. (1955). Contributions to our knowledge of British algae. XIV. Three new species from the English Lake District. Hydrobiologia 7, 219-229.

Meffert, M.-E. (1987). Planktonic unsheathed filaments (Cyanophyceae) with polar and central gas-vacuoles. I. Their morphology and taxonomy. Arch Hydrobiol Suppl 76, 315-346.

Meffert, M.-E. (1988). Limnothrix Meffert nov. gen. The unsheathed planktonic cyanophycean filaments with polar and central gas vacuoles. Arch Hydrobiol Suppl 80, 1-4 (Algol Stud 50-53, 269-276).

Murata, N., Wada, H. \& Gomboz, Z. (1992). Modes of fatty-acid desaturation in cyanobacteria. Plant Cell Physiol 33, 933-941.

Otsuka, S., Suda, S., Li, R., Watanabe, M., Oyaizu, H., Matsumoto, S. \& Watanabe, M. M. (1998). 16S rDNA sequences and phylogenetic analyses of Microcystis strains with and without phycoerythrin. FEMS Microbiol Lett 164, 119-124.

Palinska, K. A., Liesack, W., Rhiel, E. \& Krumbein, W. E. (1996). Phenotype variability of identical genotypes: the need for a combined approach in cyanobacterial taxonomy demonstrated on Merismopedialike isolates. Arch Microbiol 166, 224-233.

Persson, P.-E. (1996). Cyanobacteria and off-flavours. Phycologia 35 (Suppl. 6), 168-171.

Pringsheim, E. G. (1965). Oscillatoria agardhii var. suspensa nov. var. Kleine Mitteilungen über Flagellaten und Algen. X. Arch Mikrobiol 50, 401-413.

Saitou, N. \& Nei, M. (1987). The neighbor-joining method: a new method for reconstructing phylogenetic trees. Mol Biol Evol 4, 406- 425.

Skuja, H. (1948). Taxonomie des Phytoplanktons einiger Seen in Uppland, Schweden. Symb Bot Uppsala 9 (3), 1-399.
Skuja, H. (1956). Taxonomische und biologische Studien über das Phytoplankton schwedischer Binnengewässer. Nova Acta Reg Soc Sci Uppsala Ser 416 (3), 1-404.

Skulberg, O. M. (1990). Culture Collection of Algae, Catalogue of Strains, 1990 edn. Oslo: Norwegian Institute for Water Research.

Skulberg, O. M. \& Skulberg, R. (1985). Planktonic species of Oscillatoria (Cyanophyceae) from Norway. Characterisation and classification. Arch Hydrobiol Suppl 71 (Algol Stud 38/39), 157-174.

Skulberg, O. M. \& Skulberg, R. (1991). A comparative investigation and taxonomic relationships of Tychonema tenuis and Tychonema bourrellyi. Arch Hydrobiol Algol Stud 64, 271-279.

Stanier, R. Y., Sistrom, W. R., Hansen, T. A. \& 9 other authors (1978). Proposal to place the nomenclature of the cyanobacteria (bluegreen algae) under the rules of the International Code of Nomenclature of Bacteria. Int J Syst Bacteriol 28, 335-336.

Suda, S., Liu, Y., He, J., Hu, Z., Hiroki, M. \& Watanabe, M. M. (1998). Morphological, biochemical and physiological characteristics of Lyngbya hieronymusii var. hieronymusii (Oscillatoriales, Cyanobacteria). Phycol Res 46 (Suppl.), 51-55.

Swofford, D. L. (1999). PAUP*: phylogenetic analysis using parsimony (* and other methods), version 4.0. Program and Documentation. Sunderland, MA: Sinauer

Tamaoka, J. \& Komagata, K. (1984). Determination of DNA base composition by reverse-phase high-performance liquid chromatography. FEMS Microbiol Lett 25, 125-128.

Thompson, J. D., Higgins, D. G. \& Gibson, T. J. (1994). CLuSTAL W: improving the sensitivity of progressive multiple sequence alignment through sequence weighting, position-specific gap penalties and weight matrix choice. Nucleic Acids Res 22, 4673-4680.

Tompkins, J., De Ville, M. M., Day, J. G. \& Turner, M. F. (1995). Culture Collection of Algae and Protozoa, Catalogue of Strains. Ambleside, UK: Natural Environmental Research Council.

Turner, S. (1997). Molecular systematics of oxygenic photosynthetic bacteria. Plant Syst Evol Suppl. 11, 13-52.

Vandamme, P., Pot, B., Gillis, M., De Vos, P., Kersters, K. \& Swings, J. (1996). Polyphasic taxonomy, a consensus approach to bacterial systematics. Microbiol Rev 60, 407-438.

Van de Peer, Y., Jansen, J., De Rijk, P. \& De Wachter, R. (1997). Database on the structure of small ribosomal subunit RNA. Nucleic Acids Res 25, 111-116.

Van Goor, A. C. J. (1918). Zur Kenntnis der Oscillatoriaceen. Recl Trav Bot Neerl 15, 256-263.

Watanabe, M. M. \& Hiroki, M. (1997). NIES Collection. List of Strains, Algae and Protozoa, 5th edn. Ibaraki: National Institute for Environmental Studies, Environmental Agency.

Wayne, L. G., Brenner, D. J., Colwell, R. R. \& 9 other authors (1987). Report of the ad hoc committee on reconciliation of approaches to bacterial systematics. Int J Syst Bacteriol 37, 463-464.

Woloszynska, J. (1912). Das Phytoplankton einiger javanischer Seen, mit Berücksichtigung des Sawa-Planktons. Bull Acad Sci Cracovie B 1921, 649-709. 